\title{
Review \\ A Review of Relationship between Texture Characteristic and Mechanical Properties of Rock
}

\author{
Mahdi Askaripour ${ }^{1, *}$, Ali Saeidi ${ }^{1}{ }^{\mathbb{D}}$, Patrick Mercier-Langevin ${ }^{2}$ and Alain Rouleau ${ }^{1}$ \\ 1 Department of Applied Sciences, University of Quebec at Chicoutimi, Chicoutimi, QC G7H 2B1, Canada; \\ ali_saeidi@uqac.ca (A.S.); alain_rouleau@uqac.ca (A.R.) \\ 2 Geological Survey of Canada, Quebec City, QC G1K 9A9, Canada; patrick.mercier-langevin@canada.ca \\ * Correspondence: mahdi.askaripour1@uqac.ca
}

check for updates

Citation: Askaripour, M.; Saeidi, A.; Mercier-Langevin, P.; Rouleau, A. A Review of Relationship between Texture Characteristic and Mechanical Properties of Rock. Geotechnics 2022, 2, 262-296. https://doi.org/10.3390/ geotechnics2010012

Received: 3 February 2022

Accepted: 1 March 2022

Published: 7 March 2022

Publisher's Note: MDPI stays neutral with regard to jurisdictional claims in published maps and institutional affiliations.

Copyright: (C) 2022 by the authors. Licensee MDPI, Basel, Switzerland. This article is an open access article distributed under the terms and conditions of the Creative Commons Attribution (CC BY) license (https:// creativecommons.org/licenses/by/ $4.0 /)$.

\begin{abstract}
The textural characteristics of rocks influence their petrophysical and mechanical properties. Such parameters largely control rock mass stability. The ability to evaluate both immediate and long-term rock behaviors based on the interaction between various parameters of rock texture, petrophysical and mechanical properties is therefore crucial to many geoengineering facilities. However, due to the common lack of high-quality core samples for geomechanics and rock texture laboratory tests, single and multivariable regression analyses are conducted between mechanical properties and textural characteristics based on experimental test data. This study presents a review of how rock texture characteristics influence the geomechanical properties of a rock, and summarizes the regression equations between two aspects. More specifically, a review of the available literature on the effects of mineralogy, grain size, grain shape, packing density, foliation index, porosity, degree of weathering, and other rock physical characteristics on geomechanics is presented. Similarly, a review of the literature discussing the failure criteria of anisotropic rocks, both continuous and discontinuous, is also presented. These reviews are accompanied by a comparison of the fundamentals of these methods, describing their equations and discussing their advantages and disadvantages. This exercise has the objective of providing better guidelines on how to use these criteria, allowing for safer underground excavations via an improved understanding of how rock texture parameters affects the mechanical behavior of rocks.
\end{abstract}

Keywords: rock texture characteristic; failure criteria of anisotropic rocks; quantitative mineralogy; mechanical properties of rock

\section{Introduction}

Rock behavior under in situ stresses is an essential element to be considered when undertaking earth engineering studies [1]. However, a rock mass is generally substantially heterogeneous with contrasting types of rocks; therefore, it cannot be regarded as a homogeneous medium. Furthermore, a single rock type can have distinct textural properties (e.g., mineral species, grain size, shape, and orientation). Thus, understanding the influence of rock's texture on its geomechanical behavior is crucial. Rock behavior is related to petrophysical properties, such as density, ultrasonic P-wave velocity, magnetic susceptibility, electric resistivity and magnetic remanence, and to mechanical properties, such as uniaxial compressive strength (UCS), tensile and shear strength, and elastic properties, e.g., Young's modulus and Poisson's ratio [2]. The mechanical properties and the composition of the rocks are commonly used to obtain critical information, such as rock or slope instability, failure mechanism, strength-deformation characteristic assessment, and other engineering purposes [3]. Moreover, the most influential factors on the strength and deformation behaviors of intact rocks include mineral composition, crystal size, rock fabric, grain size and shape, hydrothermal alteration, weathering, and anisotropy [4]. Discontinuities in the rock, such as macro- and micro-fractures, bedding planes, schistosity and faults, contribute to 
its weakening, and largely control its overall stress response [5]. Anisotropy is primarily caused by schistosity, foliation and cleavage. At high metamorphic grades, a rock can become layered, substantially heterogeneous and deformed [6]. In sedimentary rocks, different grain or clast sizes characterize bedding planes and lamination. Metamorphic rocks are generally physically weaker than magmatic rocks. Increasing microporosities along the grain boundaries and simplifying grain relationships result in decreasing strength properties $[7,8]$. The main literature reviews reveal that the textural characteristics of rocks are major factors controlling variations in their geomechanical properties and their behavior in different engineering works.

The available information regarding the concept of rock textural characteristics in a rock mechanics context and the current definitions of geometrical features of rock is reviewed in this paper. The effects of rock textural characteristics on geomechanical parameters, including changes in mineralogy, are then discussed. An assessment of the influence of grain size, density, porosity, and anisotropy on geomechanical parameters and their regression analyses is also presented. An introduction and a brief discussion of failure models of anisotropic rocks based on continuous versus discontinuous criteria, and their advantages and disadvantages, are provided in the last section of this paper. Finally, key gaps in the understanding of rock textures versus rock mechanics are identified, and potential avenues for future research are highlighted.

\section{Rock Textural Characteristics}

The texture of a rock is a crucial factor in defining its geomechanical properties, including its strength. Rock texture has been defined as "the degree of crystallinity, grain size or granularity and the fabric or geometrical relationship between the constituents of a rock" [9]. The drillability, cuttability, and machinability of rocks are affected by four categories of rock characteristics, namely, textural, mechanical, structural, and weathering (Table 1).

Table 1. Classifications of rock characteristics (Adapted from [9]).

\begin{tabular}{cr}
\hline Term & Description \\
\hline Textural characteristics & $\begin{array}{c}\text { Grain size, shape and orientation, packing density, texture coefficient, mineral content, } \\
\text { cement type and degree of cementation, porosity, grain boundary or contact relationships }\end{array}$ \\
\hline Mechanical characteristics & Strength, hardness, abrasiveness, density, pore pressure \\
\hline Structural characteristics & Joints, fractures, cleavages, foliations, faults, folds, bedding, banding, and schistosity \\
\hline Weathered characteristics & Alteration and water content \\
\hline
\end{tabular}

The geometrical relationships between rock-forming minerals define a rock's texture. The geometrical features of mineral grains can be obtained from visual inspection of a rock and the study of samples under a microscope (using thin-sections), as well as through different automated, combined analytical element mapping methods [10]. Rock texture is generally considered a qualifier, and different geometrical features are considered in quantifying the texture of a rock, as summarized in Table 2. 
Table 2. Rock textural parameters (The parameters are adapted from the mentioned references).

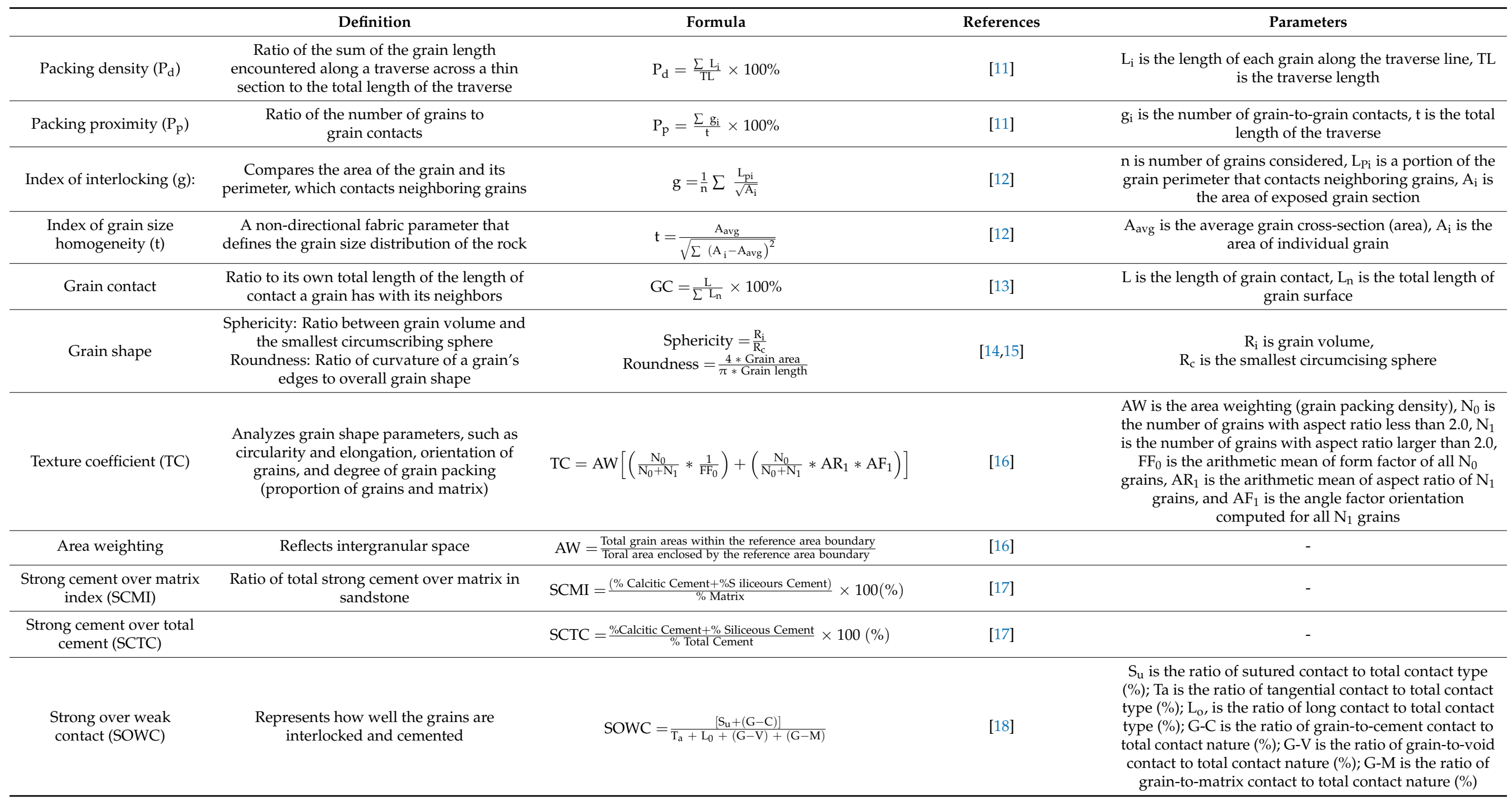


Table 2. Cont.

Formula

$\mathrm{FIX}=\frac{\sum\left(\mathrm{P}_{\mathrm{L}}\right)_{\perp}}{\sum\left(\mathrm{P}_{\mathrm{L}}\right)}$

$\mathrm{n}=\frac{\mathrm{V}_{\mathrm{v}} * 100}{\mathrm{~V}}$

$p_{\mathrm{d}}=\frac{\mathrm{M}_{\mathrm{s}}}{\mathrm{V}}$
References

Porosity

Density
Parameters

$\sum\left(\mathrm{P}_{\mathrm{L}}\right)$ and $\sum\left(\mathrm{P}_{\mathrm{L}}\right)_{\|}$are the sum of the number of grain boundaries parallel and perpendicular to the mineral fabric from all measured line transections

$\mathrm{V}_{\mathrm{v}}$ is specimen pore volume, $V$ is specimen bulk volume

$\mathrm{M}_{\mathrm{s}}$ is oven-dried grain mass of the specimen, and $V$ is specimen bulk volume 
The geometrical features presented in Table 2 are briefly explained herein. Packing density, or the relative amount of space occupied by grains in a given area, has been correlated with strength properties [21]. The packing proximity, which is also provided as a relative value, helps quantify the immediate contact intensity of grains; a value of 100 indicates that all grains are in contact. The other parameter is the index of interlocking, which quantifies the importance of grain-grain relationships and comprises both elements of packing density and proximity. Zorlu et al. in 2004 identified the presence of a linear relationship between packing density and uniaxial compressive strength (UCS) in a rock [22]. The UCS value of a rock is increased by raising the packing density. High interlocking index values indicate the high complexity of the grain boundaries. Grain size distribution is defined by the index of grain size homogeneity, as a non-directional fabric parameter [12]. The grain size homogeneity index increases with the dominance of one grain size group, and therefore provides an indication of the heterogeneity level in the rock considering granulometry. Measurements such as grain length (major axis), width (minor axis), perimeter, and area can be used to quantify grain shape [23]. Přikryl suggested that grain size and shape can be identified by using the parameters given in Table 3 [6]. With recent developments in computer technology, other grain form characterization methods, including some automated ones, have emerged. Table 4 summarizes a few popular ways of classifying grains by their shape. However, these methods are not comprehensively reviewed in this paper, and readers are referred to the cited articles. To evaluate the rock fabric for purposes of rock mechanics, the texture coefficient (TC) was developed [16]. Quantitative characteristics of grain shape, such as circularity, elongation, orientation, and degree of grain packing, can be captured by this dimensionless quantitative index (proportion of grains and matrix). Area weighting (AW) reflects the space of intergranularity in sedimentary rocks. For igneous rocks, AW equals 1 [16]. The area weighting is based on the grain packing density within the reference boundary. Tsidzi proposed a foliation intensity index based on the modal percentage of the platy prismatic grains and their corresponding shape factors to quantify foliation intensity (FIX) [19].

Table 3. Grain shape characterization methods (Adapted from [23]).

\begin{tabular}{|c|c|c|}
\hline Shape Characteristic & Definition & Comment \\
\hline Sphericity [14] & $\begin{array}{l}\text { Ratio of grain volume to that of the } \\
\text { smallest circumscribing sphere }\end{array}$ & $\begin{array}{l}\text { 2D chart developed to facilitate application } \\
\text { Measurement relates to form } 3 / 4 \\
\text { Measurement in computer programs differ from the original definition }\end{array}$ \\
\hline Roundness [15] & $\begin{array}{l}\text { Ratio of the curvature of grain } \\
\text { edges/corners to overall grain }\end{array}$ & $\begin{array}{l}\text { 2D chart developed to facilitate application } \\
\text { Measurement relates to angularity and texture } \\
\text { Measurements in computer programs differ from the original definition }\end{array}$ \\
\hline Fourier series [24] & $\begin{array}{l}\text { Shape (wave of the profile) estimated } \\
\text { by the expansion of the periphery } \\
\text { radius as a function of the angle of the } \\
\text { grain's center of gravity by } \\
\text { Fourier series }\end{array}$ & Unable to analyze highly irregular or re-entrant particles correctly \\
\hline Fourier descriptors [25] & $\begin{array}{l}\text { Calculation of shape descriptors from } \\
\text { the Fourier series coefficients }\end{array}$ & $\begin{array}{l}\text { Problems with other Fourier series methods are overcome (i.e., } \\
\text { re-entrant particles) } \\
\text { Applies FFT algorithm and utilizes boundary information only }\end{array}$ \\
\hline Fractal dimension [26] & $\begin{array}{l}2 \mathrm{D} \text { value ranging from } 0 \text { to } 1 ; \\
\text { describes the capability of a rugged } \\
\text { boundary to occupy void space }\end{array}$ & $\begin{array}{l}\text { Highly dependent on segment lengths chosen to measure profile } \\
\text { Measurement is related to roughness or texture of grain rather than form }\end{array}$ \\
\hline
\end{tabular}


Table 4. Summary of the basic microstructural parameters measured by the petrographic image analysis of thin sections (Adapted from [6,27]).

\begin{tabular}{|c|c|c|c|}
\hline Parameters & Symbol & Computation & Meaning of Parameters for Real Grains \\
\hline Area & $\mathrm{A}_{\mathrm{i}}$ & Number of pixels defining the object & Cross-section area \\
\hline Perimeter & $L_{P}$ & $\begin{array}{l}\text { Length of all edge pixels outlining } \\
\text { the object }\end{array}$ & Length of grain boundary \\
\hline $\begin{array}{l}\text { Major (minor) } \\
\text { axis length }\end{array}$ & $\begin{array}{c}\mathrm{D}_{\max } \\
\mathrm{D}_{\min } \\
\text { MajX }_{1}, \text { MajX }_{2}, \text { Maj } \mathrm{Y}_{1}, \text { Maj } \mathrm{Y}_{2} \text { are } \\
\text { the } \mathrm{X}, \mathrm{Y} \text { coordinates of } \\
\text { the endpoints }\end{array}$ & $\begin{array}{l}\text { Distance between the two points defining } \\
\text { the major axis } \\
\mathrm{D}_{\max =\sqrt{\left(\mathrm{MajX}_{2}-\mathrm{MajX}_{1}\right)^{2}-\left(\mathrm{Maj}_{2}-\mathrm{Maj}_{1}\right)^{2}}}\end{array}$ & - \\
\hline $\begin{array}{l}\text { Slope of mineral } \\
\text { principal axes }\end{array}$ & MajAS & $\begin{array}{c}\text { Angle of the major or minor axes from a } \\
\text { horizontal reference line } \\
\text { MajAS }=\alpha \tan \frac{\mathrm{Maj}_{2} \mathrm{M}_{2}-\mathrm{Maj}_{1} \mathrm{Y}_{1}}{\mathrm{Maj}_{2}-\mathrm{Maj}_{1}}\end{array}$ & - \\
\hline $\begin{array}{l}\text { Equivalent } \\
\text { diameter }\end{array}$ & $\mathrm{D}_{\text {equiv }}$ & $D_{\text {equiv }}=\frac{4 A_{i}}{\pi}$ & Grain size \\
\hline Compactness & $\mathrm{C}$ & $\begin{array}{l}\text { Shape of an object as it moves from a circle } \\
\text { to a line } \\
\qquad C=\frac{L_{p}^{2}}{A_{i}}\end{array}$ & Shape of the grain cross-section \\
\hline $\begin{array}{l}\text { Shape } \\
\text { (form) factor }\end{array}$ & SF & $\mathrm{SF}=\frac{4 \pi \mathrm{A}_{\mathrm{i}}}{\mathrm{L}_{\mathrm{p}}^{2}}$ & Circularity of grain cross-section \\
\hline Aspect ratio & $\mathrm{AR}$ & $\mathrm{AR}=\frac{\mathrm{D}_{\max }}{\mathrm{D}_{\min }}$ & Grain ellipticity \\
\hline $\begin{array}{l}\text { Grain boundary } \\
\text { smoothness }\end{array}$ & GBS & $\mathrm{GBS}=\frac{\mathrm{L}_{\mathrm{P}_{\mathrm{el}}}}{\mathrm{L}_{\mathrm{P}} \text { real }}$ & $\begin{array}{l}\text { Deviation of grain shape from the } \\
\text { smooth surface }\end{array}$ \\
\hline
\end{tabular}

The size distributions of crystals (in igneous and metamorphic rocks), grains (in sedimentary and occasionally metamorphic rocks), and occasional fragments and clasts (in sedimentary and volcanic rocks comprising clasts of previously formed rocks) are amongst the most commonly quantified aspects of rock texture [28]. The size of a crystal or grain is a measure of the space it occupies. A linear measure of size is generally used in geological applications. Figure 1 represents quantitative textural methods that can be used at different scales of interest.

Typical grain or crystal size

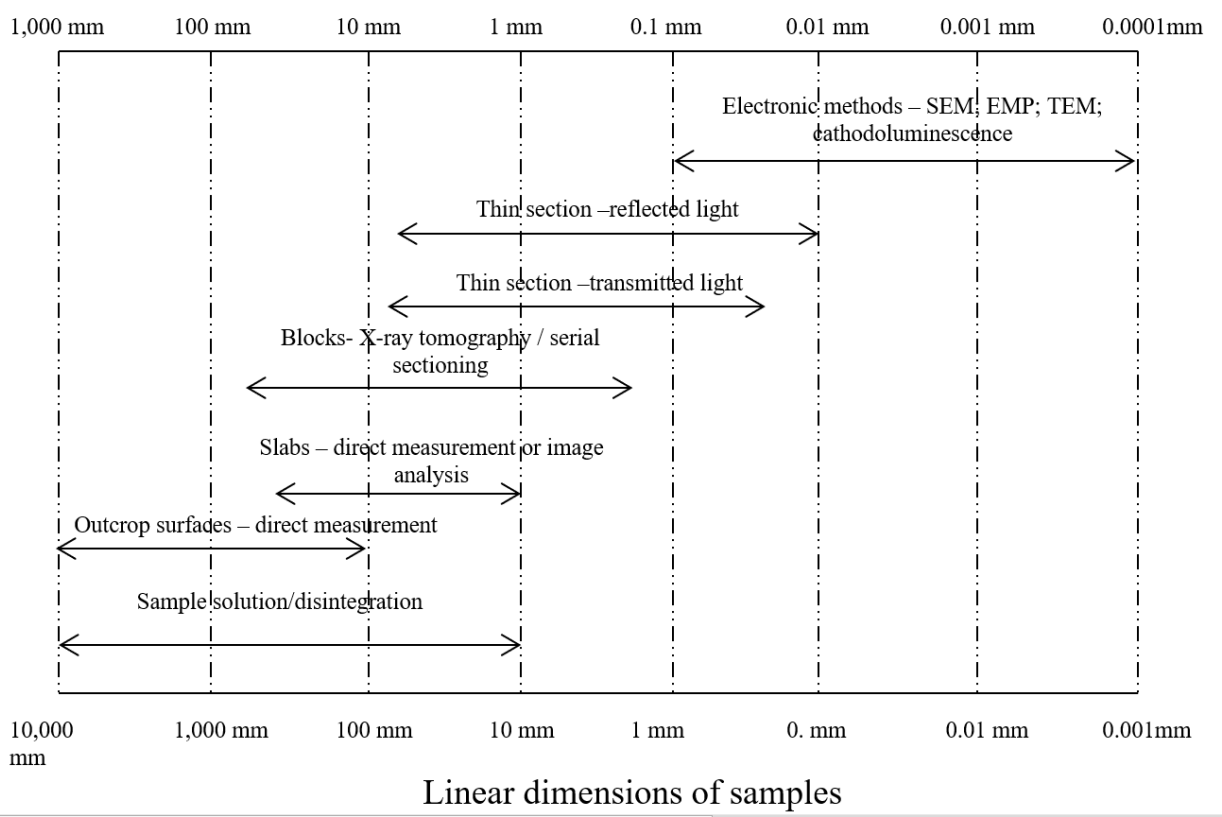

Figure 1. Measurements of crystal or grain size by analytical methods [28]. 
Weathering is another vital parameter of rock texture. The weathering or alteration process is conducted via mechanical, chemical, and biological actions, which significantly affect the engineering properties of rock mass. Some of the significant effects of weathering/alteration on rock include reductions in strength, density, and volumetric stability, as well as increments in deformability, porosity, and weatherability. Rocks can show no weathering or be completely weathered, which can be relatively quantified using visual criteria, as summarized in Table 5.

Table 5. Degree of weathering of the rock [29].

\begin{tabular}{|c|c|}
\hline Term & Description \\
\hline Unweathered/unaltered & Outer fracture planes may be stained or discolored, but no visible signs of alteration can be seen. \\
\hline Slightly weathered/altered & $\begin{array}{l}\text { Fractures may have thin fillings of altered material and are stained or discolored. It is possible } \\
\text { for the discoloration to extend outward from the fracture planes as far as } 20 \% \text { of the fracture } \\
\text { spacing (i.e., less than } 40 \% \text { of the core is discolored). }\end{array}$ \\
\hline Medium weathered/altered & $\begin{array}{c}\text { Fractures are discolored for a distance greater than } 20 \% \text { of the fracture spacing between them } \\
\text { (i.e., generally a large part of the rock). Altered material may fill fractures. (Except in poorly } \\
\text { cemented sedimentary rocks) The core does not have a friable surface, and its original texture } \\
\text { has been preserved. }\end{array}$ \\
\hline Highly weathered/altered & $\begin{array}{l}\text { Discoloration takes place throughout the rock. The surface of the core is friable and usually } \\
\text { pitted due to the washing out of highly altered minerals by drilling water. Although much of } \\
\text { the original rock texture has been preserved, grains have separated. }\end{array}$ \\
\hline Totally weathered/altered & $\begin{array}{l}\text { There is discoloration in the rock, and the core has a similar external appearance to soil. Despite } \\
\text { the rock texture being partially preserved, the grains are completely separated. }\end{array}$ \\
\hline
\end{tabular}

The anisotropy of rock also has a major influence on its geomechanical properties. Rock anisotropy can be due to the presence of cleavage, foliation, bedding planes, schistosity, joints, micro- or macro-fissures, or any other directional or planar feature caused by variations in mineral composition, grain size, crystal size, fabric, porosity, and weathering. Fabric-dependent anisotropy plays an important role in realizing the mechanical behavior of schistose or foliated rocks because such planar fabrics create mechanically weak discontinuities. Anisotropy in a rock can be primary (i.e., developed as the rocks are formed) or secondary (i.e., due to transformations or modifications to the rock after its formation in response to superimposed geological events, such as deformation, metamorphism, and alteration/weathering).

\subsection{Primary Structure}

Primary structures are similar to the micro-geological characteristics observed during the formation of various rocks. These features are influenced by the following: rock fabric anisotropy, texture, schistosity, and fissility. Microscopic features are usually related to grain size and can be found mostly on the microscopic scale. The anisotropic nature of rock is observed as follows. (1) Anisotropy in foliated metamorphic rocks, such as slate, schist, gneisses, or phyllites, may be caused by a natural orientation in the flat/long minerals or banding. (2) Anisotropic behaviors are frequently observed in stratified sedimentary rocks, including sandstone, shale, and sandstone-shale alteration, because of the presence of bedding planes. Anisotropy is mainly due to the sedimentation processes occurring in various layers (strata), or different minerals with various grain sizes. (3) Anisotropy can also be displayed by igneous rocks exhibiting flow structures similar to porous rhyolites due to weathering [30].

\subsection{Secondary Structures}

Secondary structures are also known as the macroscale features of rocks, which are defined in one word as "discontinuities". The term "discontinuities" is frequently used to refer to all structural breaks within geologic materials with a low or zero tensile strength. 
These discontinuities are defined as follows: (1) cracks and fractures, (2) bedding planes, and (3) shear planes and faults [31]. The highest degree of anisotropy is mainly observed in metamorphic rocks [32]. The anisotropic form is associated with a single set of discontinuities or weakness planes [20]. Most foliated metamorphic rocks contain fabric with preferentially parallel arrangements of flat or elongated minerals. The original rock fabric with a directional structure is modified by metamorphism. Foliation induced by the nonrandom orientation of macroscopic minerals, parallel fractures, or microscopic mineral plates, produces particularly direction-dependent rock properties [33]. Anisotropy is also viewable in bedded sedimentary rocks, such as siltstone, sandstone, shale, or sandstone-shale [34]. These metamorphic and sedimentary rocks, which are known as transversely isotropic rocks, are inherently anisotropic [32,35-37]. Transverse isotropy implies the presence of an axis of rotational symmetry at each point in the rock, and the rock has isotropic properties in the plane normal to that axis, namely, the plane of transverse isotropy [38].

Singh et al. described the concepts of the "type of anisotropy" and "anisotropy ratio". Based on the origin of the anisotropy curves, three types of anisotropy are distinguished qualitatively: "U type," “Undulatory type," and "Shoulder type" (Figure 2) [39]. The concept of the "anisotropy ratio" was presented for quantifying anisotropy in rocks, which is defined as the ratio of UCS of the rock at $\beta=90^{\circ}$ to the minimum strength observed over the range of $\beta$ from 0 to $90^{\circ}$ (Figure 3), which is written in Equation (1) as follows:

$$
\mathrm{I} \sigma_{\mathrm{c}}=\frac{\sigma_{\mathrm{ci}\left(90^{\circ}\right)}}{\sigma_{\mathrm{ci}(\min )}}
$$

where $\beta$ is the foliation angle with the load direction.
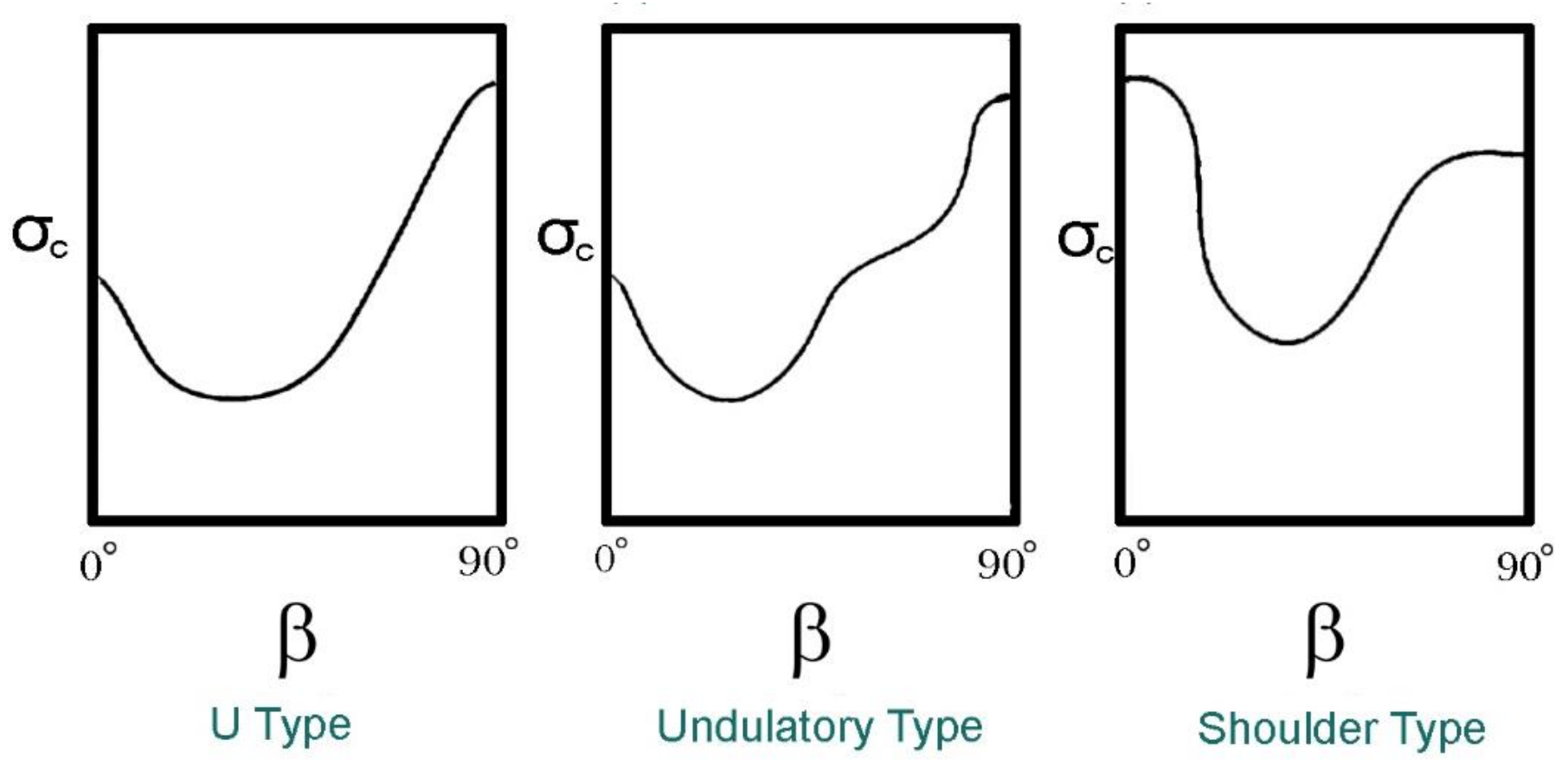

Shoulder Type

Figure 2. Classification of anisotropy for transversely isotropic rocks ( $\beta$ is foliation angle, and $\sigma_{\mathcal{C}}$ is uniaxial compressive strength of rock). 

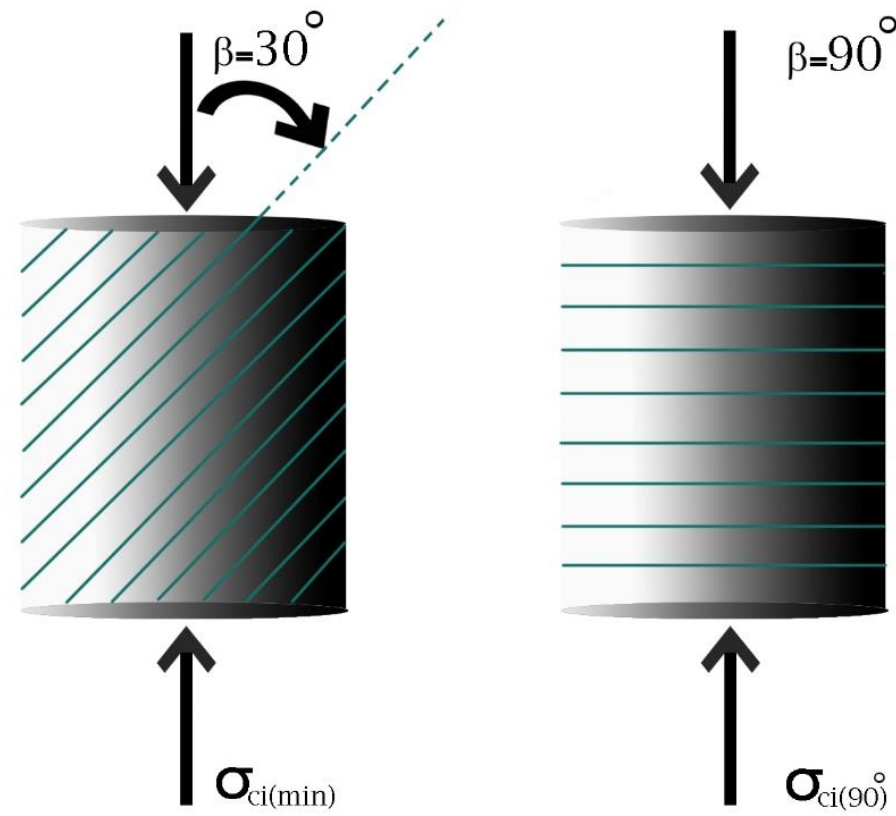

Figure 3. Minimum and maximum orientation of UCS of anisotropic intact rock.

Table 6 shows the experimental classification of anisotropic rocks based on anisotropy ratios.

Table 6. Anisotropy classification according to uniaxial compressive strength for different fine-grained rocks [32].

\begin{tabular}{ccc}
\hline Anisotropy Ratio & Class & Rock Type \\
\hline $1.0-1.1$ & Isotropic & Sandstone \\
$>2.1-2.0$ & Weakly anisotropic & Sandstone-Shale \\
$>2.0-4.0$ & Moderately anisotropic & Shale-Slates-Phyllites \\
$>4.0-6.0$ & Highly anisotropic & Slates-Phyllites \\
$>6.0$ & Very highly anisotropic & Slates-Phyllites \\
\hline
\end{tabular}

The point load strength anisotropy index was initially proposed by ISRM [40]. The index $\mathrm{I} \alpha_{(50)}$ is given as follows:

$$
\mathrm{I} \alpha_{(50)}=\frac{\mathrm{I}_{\mathrm{s}(50) \text { perpendicular }}}{\mathrm{I}_{\mathrm{s}(50) \text { parallel }}}
$$

where Is $_{(50)}$ refers to the point load indexes that are perpendicular and parallel to the foliation planes in the axial and diametrical point load tests. The studies revealed that, due to the splitting through these weakness planes, the lowest point load value is found when loading is parallel to the foliation planes [41]. A classification of anisotropic rocks was proposed by ISRM based on the point load strength index, $\mathrm{I} \alpha_{(50)}$, as given in Table 7 , while a similar classification was proposed by Tsidzi [42,43].

Table 7. Anisotropy classification based on point load index [43].

\begin{tabular}{cc}
\hline Degree of Point Load Strength Anisotropy $\left(\mathbf{I} \alpha_{(50)}\right)$ & Descriptive Term \\
\hline 1 & Isotropic \\
$1-2$ & Low-moderately anisotropic \\
$2-4$ & Highly anisotropic \\
$>4$ & Very highly anisotropic \\
\hline
\end{tabular}


Another way to determine the degree of anisotropy is to use the wave velocity anisotropy of intact rock. Tsidzi in 1997 proposed a velocity anisotropy index, VA, based on tests performed on metamorphic rocks, which is described by Equation (2) [44].

$$
\mathrm{VA}=\frac{\mathrm{V}_{\max }-\mathrm{V}_{\min }}{\mathrm{V}_{\text {mean }}}(\%)
$$

where $\mathrm{V}_{(\max )}$ is the maximum ultrasonic wave velocity, $\mathrm{V}_{(\min )}$ is the minimum velocity, and $\mathrm{V}_{\text {(mean) }}$ is the mean velocity. The classification of anisotropy based on this index is given in Table 8 .

Table 8. Anisotropy classification according to ultrasonic wave velocity [44].

\begin{tabular}{cc}
\hline Degree of Velocity Anisotropy (VA\%) & Descriptive Term \\
\hline$<2$ & Isotropic \\
$2-6$ & Fairly anisotropic \\
$6-20$ & Moderate anisotropic \\
$20-40$ & Highly anisotropic \\
$>40$ & Very highly anisotropic \\
\hline
\end{tabular}

Saroglou and Tsiambaos proposed another classification of anisotropic rocks based on the uniaxial compressive strength index $\left(I_{c}\right)$, the longitudinal velocity index $\left(I_{V p}\right)$, and the diametrical point load index $\left(\mathrm{I}_{\mathrm{d}}\right)$ [41]. This classification is presented in Table 9.

Table 9. Suggested classes for the classification of anisotropic rocks [41].

\begin{tabular}{cccc}
\hline Anisotropy Classification & Strength Index $\left(\boldsymbol{I}_{\mathrm{c}}\right)$ & Longitudinal Velocity Index $\left(\mathrm{I}_{\mathbf{V}}\right)$ & Diametrical Point Load Index $\left(\mathrm{I}_{\mathbf{d}}\right)$ \\
\hline Isotropic & $\mathrm{I} \sigma_{\mathrm{c}} \leq 1.1$ & - & $\mathrm{I}_{\mathrm{d}}=1.0$ \\
Fairly anisotropic & $1.1<\mathrm{I} \sigma_{\mathrm{c}} \leq 2.0$ & $\mathrm{I}_{\mathrm{Vp}} \leq 1.5$ & $1.0<\mathrm{I}_{\mathrm{d}} \leq 2.0$ \\
Moderate anisotropic & $2.0<\mathrm{I} \sigma_{\mathrm{c}} \leq 3.0$ & $1.5<\mathrm{I}_{\mathrm{Vp}} \leq 2.0$ & $2.0<\mathrm{I}_{\mathrm{d}} \leq 4.0$ \\
Highly anisotropic & $3.0<\mathrm{I} \sigma_{\mathrm{c}} \leq 5.0$ & $\mathrm{I}_{\mathrm{Vp}}>2.0$ & $\mathrm{I}_{\mathrm{d}}>4.0$ \\
Very highly anisotropic & $\mathrm{I} \sigma_{\mathrm{c}}>5.0$ & - & \\
\hline
\end{tabular}

To summarize, the careful characterization of a rock, in terms of both mineralogy and chemical composition, can provide key additional information to conventional mechanical tests in assessing surface or underground excavations' stability. The texture of a rock is often overlooked in the study of rock mechanics. Our review clearly shows that the mechanical behavior of a rock is determined by its physical properties, including the anisotropy of its fabric and the degree of weathering it has undergone. Several quantitative indices of rock texture have been developed in the last few decades to provide general assessments of rock quality and to interpret the variations in rock mechanical properties. In earlier work, some of these indices have been used to test large numbers of rock samples, which represented the same lithology but several different weathering grades, and thus different geomechanical states. A limited number of previous studies, however, have focused on determining the real meaning of the proposed coefficients or the real causes of rock mechanical property variations. Beside the mentioned parameters, other parameters such as permeability must also be considered in all developed models.

The aforementioned parameters define different aspects of rock texture; their relationship with the mechanical properties of rocks has been studied by many researchers. The mineral composition, grain shape and size, density, porosity, and foliation degree of the rock all influence its mechanical properties more than other texture parameters [45]. Therefore, the effect of these parameters on the mechanical properties of the rock will be discussed in the following section. 


\section{Relationships between Rock Textural Characteristics and Mechanical Properties}

The mechanical properties of a rock largely depend on its petrographic or textural characteristics. Some quantitative associations between rock petrographic characteristics and mechanical properties have been found. Therefore, the effects of these relationships on the mechanical characteristics of rock, and their extents, must be well understood as a proper frame of reference if good rock cores are unavailable for reliable tests intended to characterize rock mass.

\subsection{Mineral Composition}

The mechanical properties of rocks are markedly influenced by their mineralogical properties [17]. The strongest rocks are generally those that contain quartz as a binding material, followed by calcite (a carbonate species) and ferrous minerals (such as hematite and chromite), whereas rocks that contain clays and phyllosilicates (sheet silicates) for binding materials are weak [46]. Several authors have investigated the links between the mineral composition and geomechanical properties of different rock types. Figure 4 shows the main work of the experimental/empirical and numerical/simulation methods used for the evaluation of the effects of mineralogy and texture parameters on the geomechanical parameters of rock between 1960 and 2021. This chart represents the studies on sedimentary rock (yellow box), igneous rock (blue box), and metamorphic rock (red box). The red and green dashed lines indicate the nature of the study, that is, whether it has a substantial focus on geomechanical properties or rock texture. Researchers have recently devoted increasing attention to using simulation methods for the prediction of rock behavior with different mineralogical assemblages.

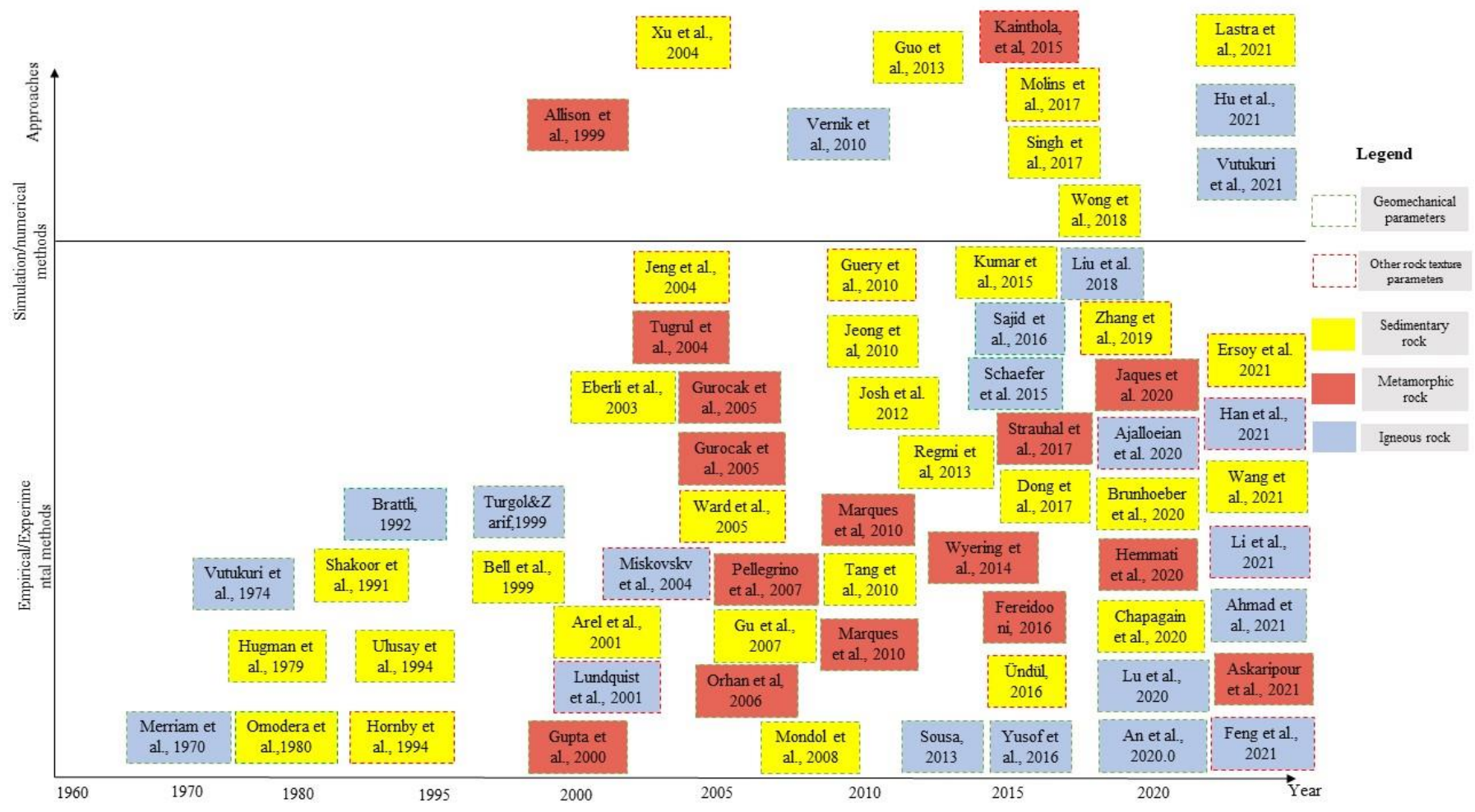

Figure 4. Main work on the effects of rock mineralogy on the geomechanical parameters of rock $[3,5,17,45,47-104]$.

The relationship between the geomechanical properties of the rock and quartz-tofeldspar ratio (QFR) was investigated [51,52,74], as presented in Table 10. 
Table 10. Regression equations between mechanical properties and quartz-to-feldspar ratio $\left(\sigma_{\mathrm{c}}, \mathrm{I}_{\mathrm{s} 50}\right.$, and $\sigma_{\mathrm{t}}$ are in $\left.\mathrm{Mpa}\right)$.

\begin{tabular}{clll}
\hline Equation & Mineral Type & Correlation & References \\
\hline$\sigma_{\mathrm{c}}=121.02 \times \mathrm{QFR}+115$ & Granite rocks & 0.79 & {$[74]$} \\
$\sigma_{\mathrm{t}}=19.54 \times \mathrm{QFR}+15$ & Granite rocks & & 0.54 \\
$\sigma_{\mathrm{c}}=-437.67 \times \mathrm{QFR}+384.82$ & Granite rocks & 0.37 & {$[51]$} \\
\hline$\sigma_{\mathrm{c}}=26.632 \times \mathrm{QFR}+24.459$ & & 0.39 & 0.16 \\
$\sigma_{\mathrm{t}}=-0.0957 \times \mathrm{QFR}+7.685$ & & $0.16]$ \\
$\mathrm{I}_{\mathrm{s} 50}=51.65 \times \mathrm{QFR}+69.49$ & & & \\
\hline
\end{tabular}

The main factors that affect the UCS of rocks based on their microtexture are mineral content, groundmass, and porosity [57]. Table 11 represents regression equations between the texture characteristic of the rock and its mechanical properties.

Table 11. Regression equations between mechanical properties and some aspects of rock texture characteristics.

\begin{tabular}{|c|c|c|c|}
\hline Equation & Reference & Parameters & $\mathbf{R}^{2}$ \\
\hline $\begin{array}{l}\sigma_{\mathrm{u}}=0.90 \mathrm{D}+2.07 \mathrm{M}+269 \\
\sigma_{\mathrm{u}}=1.07 \mathrm{D}+2.29 \mathrm{M}+258\end{array}$ & [61] & $\begin{array}{l}\text { D: mineral content of dolomite }(\%) \\
\text { M: mineral content of microcrystalline carbonate } \\
\sigma_{u} \text { is in MPa }\end{array}$ & $\begin{array}{l}0.73 \\
0.87\end{array}$ \\
\hline $\begin{array}{c}\text { Impact value }(\%)=55.13+0.50 \mathrm{M} \\
\text { Abrasion value }(\%)=3.07-0.032 \mathrm{Q} \\
\text { Abrasion value }(\%)=3.0006-0.0137 \mathrm{~F}\end{array}$ & [3] & $\begin{array}{c}\mathrm{M}=\text { Mica }(\%) \\
\mathrm{Q}=\text { Quartz }(\%) \\
\mathrm{F}=\text { Feldspar }(\%)\end{array}$ & $\begin{array}{l}0.73 \\
0.64 \\
0.71\end{array}$ \\
\hline $\mathrm{UCS}=97.058 \frac{\mathrm{C}_{\mathrm{plg}}+\mathrm{C}_{\mathrm{amf}}}{\mathrm{C}_{\mathrm{grm}}}+125.12$ & [57] & $\begin{array}{c}\text { Camf. }=\text { Amphibole content }(\%) \\
\text { CGrM = Groundmass content for all types of } \\
\text { compositions } \% \\
\text { Cplg. = Plagioclase content } \%\end{array}$ & 0.37 \\
\hline $\mathrm{UCS}=219.75 \frac{\mathrm{C}_{\mathrm{plg}}+\mathrm{C}_{\mathrm{amf}}}{\mathrm{C}_{\mathrm{grm}}^{1}}+35.728$ & [57] & $\begin{array}{l}C G r M 1=\text { Groundmass content values obtained } \\
\text { from specimens with only andesitic composition } \%\end{array}$ & 0.66 \\
\hline $\mathrm{UCS}=-7.5966 \mathrm{C}_{\mathrm{b}}+202.93$ & {$[57]$} & $\mathrm{Cb}=$ Biotite content $\%$ & -0.56 \\
\hline$v=0.0882 \frac{C_{p l g}+C_{a m f}}{C_{g r m}}+0.134$ & [57] & & 0.56 \\
\hline$v=0.1191 \frac{C_{\mathrm{plg}}+C_{\mathrm{amf}}}{\mathrm{C}_{\mathrm{grm}}^{1}}+0.1099$ & [57] & & 0.66 \\
\hline$v=0.3047 \frac{C_{\mathrm{plg}}+\mathrm{C}_{\mathrm{amf}}}{\mathrm{C}_{\mathrm{grm}}^{2}}+0.0709$ & [57] & $\begin{array}{l}\text { CGrM } 2 \text { = Groundmass content values obtained } \\
\text { from specimens with only rhyodacite composition }\end{array}$ & 0.61 \\
\hline
\end{tabular}

Multiple input interactions have been studied using multiple regression analysis. The linear models for uniaxial compressive strength and Young's modulus are provided in Table 12.

Table 12. Some significant multiple regression equations [57] $\left(\mathrm{C}_{\mathrm{plg}}\right.$. is plagioclase content in $\%, \mathrm{C}_{\mathrm{amf}}$. is amphibole content in $\%, \mathrm{C}_{\mathrm{GrM}}$. is groundmass content for all types of composition in $\%, \mathrm{M}_{\text {felds. }}$ is the mass fraction of total feldspar minerals in $\%, \mathrm{M}_{\mathrm{q}}$. is the mass fraction of quartz in $\%$. $\mathrm{n}_{\mathrm{t}}$ is total porosity, $\mathrm{F}_{\mathrm{opa}}$. is Feret's diameter of opaque minerals in $\mathrm{mm}, \mathrm{F}_{\mathrm{bio}}$. is Feret's diameter of biotite in $\mathrm{mm}$, LOI is loss-on-ignition values in \%, E is Young's modulus (Gpa), and UCS is the uniaxial compressive strength of rock in Mpa).

\begin{tabular}{cc}
\hline Equation & Correlation \\
\hline $\mathrm{UCS}=191.887\left(\frac{\mathrm{C}_{\mathrm{plg}}+\mathrm{C}_{\mathrm{amf}}}{C_{\mathrm{grm}}}\right)+155.341 \mathrm{M}_{\mathrm{felds}}+836.322 \mathrm{M}_{\mathrm{q}}-147.441$ & 0.811 \\
$\mathrm{UCS}=108.151\left(\frac{\mathrm{C}_{\mathrm{plg}}+\mathrm{C}_{\mathrm{amf}}}{C_{\text {grm }}}\right)-13.448 \mathrm{LOI}-16.017 \mathrm{n}_{\mathrm{t}}+219.914$ & 0.810 \\
$\mathrm{E}=10.268\left(\frac{\mathrm{C}_{\mathrm{plg}}+\mathrm{C}_{\mathrm{amf}}}{C_{\mathrm{grm}}}\right)-7.64 \mathrm{LOI}-1.953 \mathrm{n}_{\mathrm{t}}+58.069$ & 0.826 \\
$\mathrm{E}=7.690\left(\frac{\mathrm{C}_{\mathrm{plg}}+\mathrm{C}_{\mathrm{amf}}}{\mathrm{C}_{\mathrm{grm}}}\right)-42.543 \mathrm{~F}_{\mathrm{opa}}-11.618 \mathrm{~F}_{\mathrm{bio}}+54.776$ & 0.806 \\
\hline
\end{tabular}




\subsection{Grain Size, Density, and Porosity}

Grain size varies from very fine $(125-250 \mu \mathrm{m})$ to coarse-grained $(1-2 \mathrm{~mm})$. Previous laboratory experiments have extensively investigated the relationships between mechanical properties and mean grain size, and demonstrated that grain size has a significant mechanical influence. Brace realized that rocks with fine mineral grains have high mechanical strength, implying that grain size has an impact on mechanical properties [105]. Hoek suggested that high stress is necessary to cause failures on grain boundaries in rocks with a tightly interlocking structure [106]. Mendes et al. discovered that the mineralogical properties of granite samples correlate well with their mechanical properties, and samples with fine grains have high strength [107]. Willard and McWilliams revealed that mineral cleavage, microfracture, and grain boundaries influence the ultimate strength of rock, as well as the direction of crack propagation [108]. Hartley indicated that intergranular bonding had a major impact on the mechanical features of sandstones, and concluded that it is possible to determine mechanical properties by counting the contacts between grains and by looking at the types of grains [109]. Onodera and Asoka indicated that strength is significantly reduced as the grain size in igneous rock increases [45]. Singh investigated the relationship between the mean grain size of the rock with UCS and fatigue strength [110]. The fatigue strength of the rock has an inverse relationship with its mean UCS because the uniaxial compressive strength varies with different grain sizes. Shakoor and Bonelli indicated that sandstone density, percent absorption, total pore volume, and grain-to-grain content are all closely related to compressive strength, tensile strength, and Young's modulus values [5]. The compressive strength, tensile strength, and Young's modulus were all high in the sandstone with high densities, low percent absorption, low total pore volume, and high percentages of saturated contacts. In addition, the percentage of angular grains had only a weak influence on strength and elastic properties. Ulusay et al. concluded that grain size, packing proximity, percent grain-to-grain contacts, and grain-to-matrix contacts have the largest impact on Young's modulus. Young's modulus increases with the increase in the first three parameters [60]. Increased grain-to-matrix contacts reduce stiffness; therefore, Young's modulus is inversely related to grain-to-matrix contacts. The relationship between these parameters is presented in Table 13. Akesson et al. showed that abrasion and fragility are dependent on the grain size, despite the important role of the shape and arrangement of the minerals [111]. Tugrul and Zarif found linear equations between the UCS and grain size of granite rock [74]. Ündül concluded that the UCS decreases as the total porosity increases. Furthermore, the Young's modulus decreases as the grain size of biotite rises [57]. A linear relationship exists between the mean grain size and the hardness value [112]. The mean grain size increases with mean hardness, while the normative hardness decreases with grain size. A decreasing mean grain size improves resistance to wearing and impact forces. Raisänen indicated that the abrasion value is linearly related to grain size [113]. In sedimentary rocks, all strength properties decrease with increasing porosity. Research on coal rocks has revealed a linear decrease in the UCS with an increase in porosity [114]. Yusof and Zabidi indicated that the uniaxial strength relationship is indirectly proportionate to the size of the grain, which thus decreases with the increase in grain size [52]. The researchers found the regression equations between the mechanical properties and the grain sizes of rocks primarily through experiments. Table 14 shows the regression equations between the grain size and mechanical parameters of rocks. 
Table 13. Relationship between some aspects of rock texture [60] (unit weight in $\mathrm{KN} / \mathrm{m}^{3}$, point load index in $\mathrm{MPa}$, quality index in \%, porosity in \%, uniaxial compressive strength in MPa, Young's modulus in (GPa), mean grain size in $\mathrm{mm}$; all petrographic characteristics given as independent variables are in percent).

\begin{tabular}{|c|c|c|}
\hline Relationship & Prediction Equation & Correlation Coefficient \\
\hline $\begin{array}{l}\text { Unit Weight }(\mathrm{y}) \\
\text { Mean grain size }(\mathrm{x}) \\
\text { Rock fragment }(\mathrm{x}) \\
\text { Percent matrix }(\mathrm{x})\end{array}$ & $\begin{array}{c}y=25.77-1.21 x \\
y=26.08-0.017 x \\
y=25.03+0.03 x\end{array}$ & $\begin{array}{c}-0.54 \\
-0.54 \\
0.53\end{array}$ \\
\hline $\begin{array}{l}\text { Point Load Index }(\mathrm{y}) \\
\text { Round grain }(\mathrm{x}) \\
\text { Angular grain }(\mathrm{x}) \\
\text { Sutured contacts }(\mathrm{x}) \\
\text { Rock fragment }(\mathrm{x}) \\
\text { Grain to void }(\mathrm{x})\end{array}$ & $\begin{array}{c}\mathrm{y}=4.43-0.78 \mathrm{x} \\
\mathrm{y}=3.55+0.08 \mathrm{x} \\
\mathrm{y}=1.87+0.07 \mathrm{x} \\
\mathrm{y}=4.14-0.02 \mathrm{x} \\
\mathrm{y}=3.53-0.13 \mathrm{x}\end{array}$ & $\begin{array}{l}-0.68 \\
0.69 \\
0.55 \\
-0.52 \\
-0.61\end{array}$ \\
\hline $\begin{array}{l}\text { Quality Index (y) } \\
\text { Packing proximity }(\mathrm{x}) \\
\text { Grain to grain }(\mathrm{x}) \\
\text { Grain to matrix }(\mathrm{x}) \\
\text { Rock fragment }(\mathrm{x}) \\
\text { Percent matrix }(\mathrm{x})\end{array}$ & $\begin{array}{c}y=85.48-0.33 x \\
y=84.37-0.32 x \\
y=55.57+0.25 x \\
y=71.82-0.28 x \\
y=55.06+0.46 x\end{array}$ & $\begin{array}{c}-0.55 \\
-0.55 \\
0.53 \\
-0.74 \\
0.68\end{array}$ \\
\hline $\begin{array}{c}\text { Porosity (y) } \\
\text { Mean grain size }(\mathrm{x}) \\
\text { Degree of sorting (x) } \\
\text { Grain to void (x) } \\
\text { Rock fragment }(\mathrm{x})\end{array}$ & $\begin{array}{c}\mathrm{y}=2.31+2.38 \mathrm{x} \\
\mathrm{y}=1.67+2.15 \mathrm{x} \\
\mathrm{y}=2.62+0.17 \mathrm{x} \\
\mathrm{y}=1.61+0.64 \mathrm{x}\end{array}$ & $\begin{array}{l}0.56 \\
0.65 \\
0.59 \\
0.59\end{array}$ \\
\hline $\begin{array}{c}\text { Uniaxial Compressive Strength }(\mathrm{y}) \\
\text { Round grain }(\mathrm{x}) \\
\text { Angular grain }(\mathrm{x}) \\
\text { Sutured contacts }(\mathrm{x})\end{array}$ & $\begin{array}{c}y=97.17-1.6 x \\
y=61.96+1.59 x \\
y=33.37+2.04 x\end{array}$ & $\begin{array}{c}-0.71 \\
0.70 \\
0.82\end{array}$ \\
\hline $\begin{array}{l}\text { Young's Modulus }(y) \\
\text { Mean grain size }(x) \\
\text { Packing proximity }(x) \\
\text { Grain to grain }(x) \\
\text { Grain to matrix }(x)\end{array}$ & $\begin{array}{c}y=6.4+4.13 x \\
y=-0.98+0.11 x \\
y=-0.71+0.11 x \\
y=9-0.74 x\end{array}$ & $\begin{array}{c}0.70 \\
0.86 \\
0.887 \\
-0.75\end{array}$ \\
\hline $\begin{array}{l}\text { Poisson's ratio }(\mathrm{y}) \\
\text { Packing density }(\mathrm{x}) \\
\text { Packing proximity }(\mathrm{x}) \\
\text { Grain to grain }(\mathrm{x})\end{array}$ & $\begin{array}{l}y=0.44-0.0024 x \\
y=0.375-0.002 x \\
y=0.364-0.002 x\end{array}$ & $\begin{array}{l}-0.77 \\
-0.90 \\
-0.86\end{array}$ \\
\hline
\end{tabular}

Table 14. Regression equations between geomechanical properties and mean grain size (adapted from [60]). ( $\sigma_{\mathrm{c}}$ is unconfined compressive strength in $\mathrm{MPa}$; $\sigma$ is compressive strength in $\mathrm{MPa}$; $\mathrm{D}_{\text {mean }}$ is the mean grain size of all constitutive minerals in $\mathrm{mm} ; \mathrm{D}_{\text {mean }}^{\text {quartz }}, \mathrm{D}_{\text {mean }}^{\text {plagioclase }}$, and $\mathrm{D}_{\text {mean }}^{\mathrm{k}-\mathrm{feldspar}}$ mean are, respectively, the mean grain sizes of quartz, plagioclase, and K-feldspar minerals in mm; $\mathrm{P}$ is the confining pressure in $\mathrm{MPa} ; \mathrm{a}$ and $\mathrm{b}$ are empirically determined constants that depend on mean grain size).

\begin{tabular}{|c|c|c|c|}
\hline Equation & Minerals & Correlation & References \\
\hline $\begin{array}{c}\sigma_{\mathrm{c}}=128.52 * \mathrm{D}_{\text {mean }}^{\text {quartz }}+248 \\
\sigma_{\mathrm{c}}=54.73 * \mathrm{D}_{\text {mean }}^{\text {plagioclase }}+204 \\
\sigma_{\mathrm{c}}=21.12 * \mathrm{D}_{\text {mean }}^{\mathrm{k}-\text { feldspar }}+20 \\
\sigma_{\mathrm{c}}=-1.29 * \log \left(\mathrm{D}_{\text {mean }}\right)+5.38\end{array}$ & Granitic rock & $\begin{array}{l}\mathrm{R}^{2}=0.81 \\
\mathrm{R}^{2}=0.83 \\
\mathrm{R}^{2}=0.91 \\
\mathrm{R}^{2}=0.71\end{array}$ & [115] \\
\hline $\begin{array}{c}\sigma_{\mathrm{c}}=32.57 * \frac{1}{\sqrt{\mathrm{D}_{\text {mean }}}}+147.99 \\
\sigma=\sigma_{\mathrm{c}}+\mathrm{a}\left(\mathrm{D}_{\text {mean }}\right) *\left[1-\mathrm{e}^{-\mathrm{b}\left(\mathrm{D}_{\text {mean }}\right) * \mathrm{p}}\right.\end{array}$ & $\begin{array}{l}\text { Marble } \\
\text { Different lithology }\end{array}$ & $\begin{aligned} \mathrm{R}^{2} & =0.96 \\
\mathrm{R}^{2} & =0.71\end{aligned}$ & $\begin{array}{l}{[116]} \\
{[117]}\end{array}$ \\
\hline
\end{tabular}

Porosity also plays a significant role in the geomechanical parameters of rock. Bell and Lindsay reported the highly significant relationship of porosity with UCS and tensile strength [73]. The UCS and tensile strength decrease as porosity increases. The total 
porosity and dry unit weight are linearly related. As porosity increases, the dry unit weight decreases [74]. Fahy and Guccione suggested a correlation between the compressive strength of rocks and the percentage of cement, and the mean grain size is as follows (Equation (3)) [118]:

$$
\text { UCS }=167.7-0.52(\text { total percent cement })-320.9 \text { (mean grain size })
$$

where UCS is in $\mathrm{MN} / \mathrm{m}^{2}$, and mean grain size is in $\mathrm{mm}$.

Shakoor and Bonelli studied the effects of the petrographic characteristics of sandstone on the mechanical properties of the rocks, and reported that sandstones with high density, low absorption percentage, low total pore volume, and a high percentage of sutured contacts exhibited high values of compressive strength, tensile strength, and Young's modulus [5]. They proposed several empirical equations for the relationships of the petrographic characteristics of sandstone with the mechanical properties of the rocks, as written in Table 15.

Table 15. Regression equations for the prediction of geomechanical properties [5] (uniaxial compressive strength in psi, density in pcf, tensile strength in psi, Young's modulus $\times 10^{6}$ in psi, absorption in $\%$, total pore volume in cc/gm, sutured contacts in \%).

\begin{tabular}{|c|c|c|}
\hline Relationship & Prediction Equation & Correlation \\
\hline $\begin{array}{c}\text { Uniaxial compressive strength }(y) \\
\text { Density }(x)\end{array}$ & $y=668.2 x-83366$ & 0.98 \\
\hline $\begin{array}{l}\text { Tensile strength (y) } \\
\text { Density (x) }\end{array}$ & $y=30.1 x-3734$ & 0.98 \\
\hline $\begin{array}{l}\text { Young's modulus (y) } \\
\text { Density }(x)\end{array}$ & $y=0.1635 x-21.25$ & 0.91 \\
\hline $\begin{array}{l}\text { Uniaxial compressive strength }(y) \\
\text { Absorption }(x)\end{array}$ & $y=3117.5 x+26915$ & -0.97 \\
\hline $\begin{array}{l}\text { Tensile strength }(\mathrm{y}) \\
\text { Absorption }(\mathrm{x})\end{array}$ & $y=-168.8 x+1363$ & -0.97 \\
\hline $\begin{array}{l}\text { Young's modulus (y) } \\
\text { Absorption }(\mathrm{x})\end{array}$ & $y=-0.8125 x+6.075$ & -0.93 \\
\hline $\begin{array}{l}\text { Uniaxial compressive strength }(y) \\
\text { Pore volume }(x)\end{array}$ & $y=-13217 \log x-5581$ & -0.98 \\
\hline $\begin{array}{c}\text { Tensile strength }(\mathrm{y}) \\
\text { Pore volume }(\mathrm{x})\end{array}$ & $y=-811 \log x-501$ & -0.98 \\
\hline $\begin{array}{l}\text { Young's modulus }(\mathrm{y}) \\
\text { Pore volume }(\mathrm{x})\end{array}$ & $y=-4.381 \log x-3.531$ & -0.97 \\
\hline $\begin{array}{l}\text { Uniaxial compressive strength }(y) \\
\text { Sutured contacts }(x)\end{array}$ & $y=2354.6 x-28637$ & 0.70 \\
\hline $\begin{array}{l}\text { Tensile strength }(y) \\
\text { Sutured contacts }(x)\end{array}$ & $y=95.7 x-1120$ & 0.72 \\
\hline $\begin{array}{l}\text { Young's modulus (y) } \\
\text { Sutured contacts }(\mathrm{x})\end{array}$ & $y=0.5273 x-6.91$ & 0.89 \\
\hline
\end{tabular}

Chatterjee and Mukhopadhyay developed a series of equations to link the petrophysical to the geomechanical properties of rock [119]. The samples were collected from the basement rocks of the Krishna-Godavari and Cauvery basins in India. These equations are presented in Table 16. 
Table 16. Regression analysis of core samples in the Krishna-Godavari and Gauvery basins [119] (uniaxial compressive strength in Mpa, dry density in $\mathrm{kg} / \mathrm{m}^{3}$, tensile strength in $\mathrm{MPa}$, effective porosity in \%, Young's modulus in GPa).

\begin{tabular}{|c|c|c|}
\hline Basin & Parameters Related & Regression Equation and Correlation \\
\hline Krishna-Godavari & $\begin{array}{l}\text { Uniaxial compressive strength }(y) \text {, dry density }(x) \\
\text { Uniaxial compressive strength }(y) \text {, tensile strength }(x) \\
\text { Uniaxial compressive strength }(y) \text {, effective porosity }(x) \\
\text { Young's modulus (y), uniaxial compressive strength }(x)\end{array}$ & $\begin{array}{c}\mathrm{y}=55.27 \mathrm{x}-100.72, \mathrm{R}^{2}=0.89 \\
\mathrm{y}=10.33 \mathrm{x}^{0.89}, \mathrm{R}^{2}=0.94 \\
\mathrm{y}=64.23 \mathrm{e}^{-0.085 \mathrm{x}}, \mathrm{R}^{2}=0.92 \\
\mathrm{y}=8.43 \mathrm{e}^{0.029 x}, \mathrm{R}^{2}=0.95\end{array}$ \\
\hline Gauvery & $\begin{array}{l}\text { Uniaxial compressive strength }(y) \text {, dry density }(x) \\
\text { Uniaxial compressive strength }(y) \text {, tensile strength }(x) \\
\text { Uniaxial compressive strength }(y) \text {, effective porosity }(x) \\
\text { Young's modulus }(y) \text {, uniaxial compressive strength }(x)\end{array}$ & $\begin{array}{c}y=37.47 x-63.11, R^{2}=0.98 \\
y=6.89 x+5.39, R^{2}=0.93 \\
y=34.44 e^{-0.44 x}, R^{2}=0.87 \\
y=3.73 e^{0.064 x}, R^{2}=0.91\end{array}$ \\
\hline
\end{tabular}

Tamrakar et al. studied the relationships of many petrographic characteristics of rocks with their geomechanical properties [120]. The samples were sandstone from the foothills of the Himalayas. These equations are presented in Table 17.

Table 17. Prediction model of multiple regression for physical and mechanical indexes [120] (SHH is Schmidt hammer hardness, UCS is uniaxial compressive strength in $\mathrm{MPa}$, DOI is the degree of induration, PLI is point load index in Mpa, porosity is in $\%, \mathrm{G}-\mathrm{C}$ is in $\%, \mathrm{G}-\mathrm{V}$ is in $\%, \mathrm{Cc}$ is in $\%, \mathrm{E}_{\mathrm{S}}$ is Secant modulus in GPa, $E_{t}$ is the tangent modulus in GPa. $P_{\text {dry }}$ is dry density is in $\mathrm{Kg} / \mathrm{m}^{3}$, and $\mathrm{P}_{\text {sat }}$ is saturated density in $\mathrm{Kg} / \mathrm{m}^{3}$ ).

\begin{tabular}{|c|c|c|}
\hline Predictor & Constant & Equation and Correlation Coefficient \\
\hline Density $\left(\rho_{\text {dry }}\right)$ & $\begin{array}{c}\mathrm{C}_{\mathrm{C}} \\
\mathrm{P}_{\mathrm{cc}} \\
\mathrm{M}_{\mathrm{Z}} \\
\text { SCTC } \\
\text { Void } \\
\text { SCMI }\end{array}$ & $\begin{array}{c}\rho_{\text {dry }}=1910+456 \mathrm{SCTC}-17.16 \text { Void }+1.52 \mathrm{SCMI}-4.60 \mathrm{CC}+3.34 \mathrm{P}_{\mathrm{cc}}+67.84 \mathrm{M}_{\mathrm{z}} \\
\mathrm{R}^{2}=0.76\end{array}$ \\
\hline $\begin{array}{l}\text { Saturated } \\
\text { Density }\left(\rho_{\text {sat }}\right)\end{array}$ & $\begin{array}{l}\text { SCTC } \\
\text { SCMI } \\
\text { Void } \\
\mathrm{C}_{\mathrm{c}} \\
\mathrm{P}_{\mathrm{d}} \\
\mathrm{P}_{\mathrm{cc}}\end{array}$ & $\begin{array}{c}\rho_{\mathrm{sat}}=2440+318.6 \mathrm{SCTC}+0.22 \mathrm{SCMI}-5.15 \text { Void }-4.27 \mathrm{C}_{\mathrm{c}}-4.11 \mathrm{P}_{\mathrm{d}}+5.67 \mathrm{P}_{\mathrm{cc}} \\
\mathrm{R}^{2}=0.66\end{array}$ \\
\hline Porosity (n) & $\begin{array}{c}\text { SCTC } \\
\text { Void } \\
\text { SOWC } \\
\text { G-C } \\
\text { G-V } \\
\text { C }_{c}\end{array}$ & $\begin{array}{c}\mathrm{n}=7.93-5.10 \mathrm{SCTC}+0.82 \text { Void }-\begin{array}{c}1.00 S O W C \\
\mathrm{R}^{2}=0.66\end{array} \\
\end{array}$ \\
\hline $\mathrm{SHH}$ & $\begin{array}{c}\text { Void } \\
\psi_{\mathrm{p}}\end{array}$ & $\begin{array}{c}\text { SHH }=-32.80-1.32 \text { Void }+95.68 \psi_{p} \\
R^{2}=0.23\end{array}$ \\
\hline PLI $\left(\right.$ Is $\left._{50}\right)$ & $\begin{array}{c}\text { Void } \\
\text { SCTC } \\
\text { SOWC } \\
\text { G_V } \\
\text { Lo }\end{array}$ & $\begin{array}{c}\mathrm{Is}_{50}=1.62-0.19 \text { Void }-0.06 \mathrm{SCTC}+0.23 \mathrm{SOWC}+0.04 \mathrm{GV}_{\mathrm{V}}-0.002 \mathrm{Lo} \\
\mathrm{R}^{2}=0.49\end{array}$ \\
\hline UCS & $\begin{array}{l}\text { Void } \\
\text { SOWC } \\
\text { G_V } \\
\text { Lo } \\
\text { Cc }\end{array}$ & 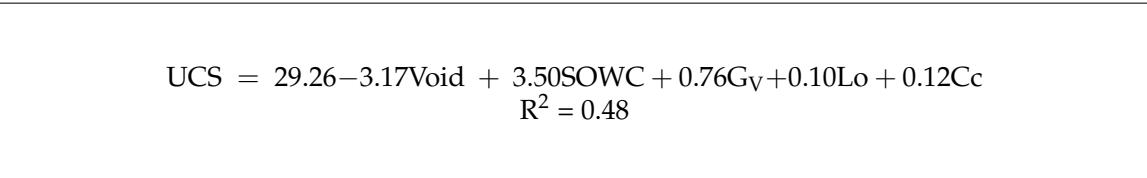 \\
\hline
\end{tabular}


Table 17. Cont.

\begin{tabular}{|c|c|c|}
\hline Predictor & Constant & Equation and Correlation Coefficient \\
\hline $\begin{array}{l}\text { Secant } \\
\text { modulus }\left(E_{s}\right)\end{array}$ & $\begin{array}{c}\text { Void } \\
\text { SOWC } \\
\text { Lo } \\
\text { G_V }\end{array}$ & 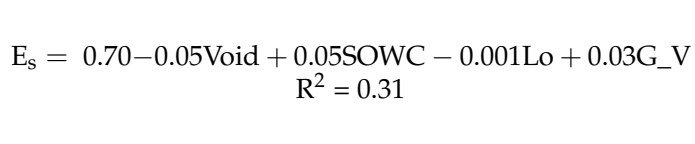 \\
\hline $\begin{array}{c}\text { Tangent } \\
\text { Modulus }\left(\mathrm{E}_{\mathrm{t}}\right)\end{array}$ & $\begin{array}{c}\text { Void } \\
\text { SOWC } \\
\text { Lo } \\
\text { G_V }\end{array}$ & $\begin{array}{c}\mathrm{E}_{\mathrm{t}}=0.84-0.06 \text { Void }+0.05 \text { SOWC }-0.001 \mathrm{Lo}+0.03 \mathrm{G}_{-} \mathrm{V} \\
\mathrm{R}^{2}=0.38\end{array}$ \\
\hline $\begin{array}{l}\text { Modulus } \\
\text { ratio }(\mathrm{MR})\end{array}$ & $\begin{array}{c}\text { Void } \\
\text { SCTC } \\
\text { G-G } \\
P_{\mathrm{d}}\end{array}$ & $\begin{array}{c}\mathrm{MR}=14+1.58 \text { Void }-6.30 \mathrm{SCTC}+0.06 \mathrm{G}_{\mathrm{G}}+0.19 \mathrm{P}_{\mathrm{d}} \\
\mathrm{R}^{2}=0.21\end{array}$ \\
\hline
\end{tabular}

Ündül indicated that phenocrysts (i.e., conspicuous crystals that are substantially larger than the matrix in magmatic and volcanic rocks) and groundmass are regarded as the main factors influencing crack propagation [57]. An increase in phenocryst content leads to an increase in radial strain and an increase in Poisson's ratio. Cracks tend to align parallel to the applied load as the groundmass content (low phenocryst content) increases. Increased groundmass reduces the Poisson's ratio compared to samples with high phenocryst contents. Table 18 presents empirical equations that show how petrophysical properties and microtextural variables are related.

Table 18. Linear regression between mechanical properties and some aspects of rock texture [57] ( $\mathrm{M}_{\mathrm{g}}$ is the mass fraction of quartz $(\%), n_{t}$ is total porosity, CGrM is the groundmass content for all types of compositions, $\mathrm{C}_{\text {grm }}^{1}$ is the groundmass content values obtained only from the specimen of andesitic composition, $v$ is Poisson's ratio, $E$ is Young's modulus (GPa), $C_{\text {grm }}^{2}$ is groundmass content values obtained only from the specimen of rhyodacite composition, $\mathrm{A}_{\text {ngopa }}$. is the angularity of opaque minerals, $F_{\mathrm{opa}}$. is Feret's diameter of opaque minerals $(\mathrm{mm})$, Fbio is Feret's diameter of biotite $(\mathrm{mm})$, $\mathrm{P}_{\mathrm{opa}}$. is the perimeter of opaque minerals, LOI is an indicator of the weathering stage of rock (\%), and UCS is uniaxial compressive strength $(\mathrm{MPa})$.

\begin{tabular}{cc}
\hline Equation & Correlation Coefficient \\
\hline $\mathrm{UCS}=5.2455 \mathrm{M}_{\mathrm{q}}+102.36$ & 0.47 \\
$\mathrm{UCS}=-13.531 \mathrm{n}_{\mathrm{t}}+246.23$ & -0.64 \\
$v=-0.0026 \mathrm{C}_{\mathrm{grm}}+0.3406$ & -0.62 \\
$v=-0.0038 \mathrm{C}_{\mathrm{grm}}^{1}+0.4078$ & -0.72 \\
$v=-0.0038 \mathrm{C}_{\mathrm{grm}}^{2}+0.444$ & -0.88 \\
$\mathrm{E}=-6.6561 \mathrm{LOI}+52.326$ & -0.55 \\
$\mathrm{E}=-57.69 \mathrm{~F}_{\mathrm{apa}}+58.573$ & -0.72 \\
$\mathrm{E}=-18.502 \mathrm{P}_{\mathrm{apa}}+55.578$ & -0.69 \\
$\mathrm{E}=-26.325 \mathrm{~F}_{\mathrm{bio}}+52.743$ & -0.66 \\
$\mathrm{E}=106.78 \mathrm{Ang}_{\mathrm{opa}}+36.92$ & 0.63 \\
\hline
\end{tabular}

\subsection{Texture Coefficient (TC)}

The texture coefficient has often been used to quantify the characteristics of rock texture. In this approach, rock material textures depend on the geometrical relation between the mineral grains and the matrix [121]. Rocks comprising hard minerals tend to have rough surface textures and high strength properties. Soft minerals are found in clay minerals and organic matters. The rest of the rock-forming minerals are hard minerals. To define the texture coefficient, Howarth and Rowlands considered morphological characteristics such as grain size, grain shape, grain orientation, porosity, and matrix materials [16]. Table 19 represents the linear regression equations between the UCS and TC of rocks, which are extracted from different studies. Various types of rocks show a linear increase in UCS as the texture coefficient increases, except for fault breccia (i.e., broken or partly 
disaggregated rocks in a fault zone). Ersoy and Waller found a positive linkage between UCS and texture coefficient for various sedimentary and igneous rocks [122]. A strong link in sandstone, siltstone, marl, shale, and limestone has been validated [121]. Most experiments have shown that UCS is increased linearly by raising the texture coefficient in various rock forms [122,123]. However, contradictory correlations are found between TC and strength [124]. The possible explanations for these contradictory correlations may be as follows. Complicated rock texture characteristics cannot be effectively expressed as a coefficient of texture by one index. For example, fault breccia, which comprises broken mineral grains filled with a fine-grained matrix, may have substantially different mineral properties than other types of rocks, such as sandstone, limestone, and granite, resulting in different relationships between UCS and grain size.

Table 19. Linear empirical equations between UCS and TC ( $\sigma_{\mathrm{c}}$ is uniaxial compressive strength in $\mathrm{MPa} ; \sigma_{\mathrm{t}}$ is indirect tensile strength in MPa; TC is texture coefficient).

\begin{tabular}{cccc}
\hline Equation & Mineral Type & Correlation & Reference \\
\hline$\sigma_{\mathrm{c}}=70.83 \times \mathrm{TC}+12.83$ & Sandstone, siltstone, marl, shale, limestone & 0.76 & 0.87 \\
$\sigma_{\mathrm{c}}=72.37 \times \mathrm{TC}+10.38$ & Limestone & 0.93 & {$[123]$} \\
$\sigma_{\mathrm{c}}=106.51 \times \mathrm{TC}+7.46$ & Sandstone, siltstone, marl, shale & 0.90 & {$[124]$} \\
\hline$\sigma_{\mathrm{c}}=-131.86 \times \mathrm{TC}+86.20$ & Fault breccia & 0.69 & 0.62 \\
\hline$\sigma_{\mathrm{t}}=8.75 \times \mathrm{TC}-3.32$ & Sandstone, limestone, siltstone, granite, diorite & 0.91 & {$[122]$} \\
$\sigma_{\mathrm{c}}=110.01 \times \mathrm{TC}-46.12$ & Saturated rock material & 0.92 & {$[16]$} \\
\hline$\sigma_{\mathrm{c}}=96.40 \times \mathrm{TC}-56.48$ & Dry rock material & & \\
$\sigma_{\mathrm{c}}=104.80 \times \mathrm{TC}-55.14$ & & &
\end{tabular}

\subsection{Rock Anisotropy}

The anisotropy of a rock influences its behavior in engineering analyses. Aagaard investigated the effect of foliation angle on the diametrical point load index of two gneisses and mica schist rocks [125]. The point load index decreases as the foliation angle increases. Behrestaghi et al. indicated that quartzitic and chlorite schists with a low amount of mica exhibit high tensile strength and UCS at all foliation angles [35]. Nasseri et al. studied the impact of anisotropy on the UCS of quartzitic, chlorite, quartz mica, and biotite schists [126]. They showed that all samples displayed the maximum strength when $\beta=90^{\circ}$, due to the uniform distribution of stress throughout the anisotropy planes, compared with when the foliations are inclined. AL-Harthi studied 10 large blocks of Ranyah sandstone, which had two sets of discontinuities instead of one set of discontinuities [20]. Because of the superimposed effects of bedding and microfissures, an anisotropy curve in the form of a W curve was obtained (Figure 5).

Khanlari et al. noted that the metamorphic foliation angles of samples could influence rock strength directly [127]. The lowest rock strength was observed when the angle of foliation was from $0^{\circ}$ to $30^{\circ}$. By contrast, the maximum value of rock strength was achieved when the foliation angle was $90^{\circ}$. Ali et al. investigated the behavior of banded amphibolite rocks in terms of strength and deformation anisotropy [128]. The results show that under UCS testing, the amphibolite had a U-shaped anisotropy with maximum strength at $\beta$ $=90^{\circ}$, and minimum strength was reported when $\beta=30^{\circ}$. The results of the elastic deformation test show the absence of a relationship between the microstructure features of subtype amphibolite rocks (metamorphosed at high temperatures and pressures) that control modulus "shape anisotropy." The researchers also studied the relationship between the anisotropy and tensile strengths of rocks. Several researchers have demonstrated that fractures in brittle materials can occur due to tensile stress. Therefore, the tensile strength is an important aspect of the failure resistance of rock. Hobbs reported that the maximum tensile strength is obtained when the angle of foliation is perpendicular to the load direction [129]. This phenomenon indicates that tensile strength is larger in low degrees of anisotropy than in high degrees of anisotropy. The low value may be attributed 
to the low cohesion between rock materials, or the presence of microcracks that directly connect to the anisotropy.

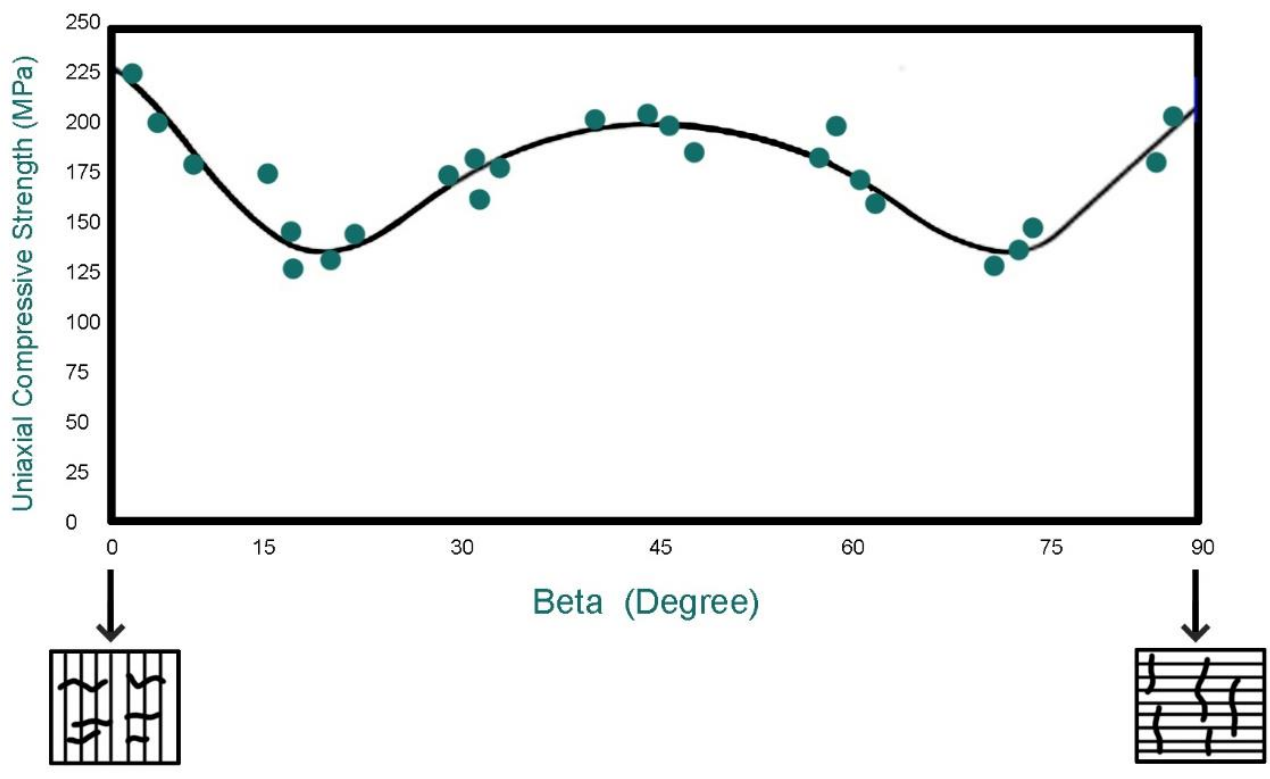

Figure 5. Correlation between the UCS of Ranyah sandstone and the angle of oreintation $\beta$ [20].

Shear strength refers to the strength of a rock, or the structural failure when the rock fails in shear. A rock that encounters a shear load slides along a plane, failing parallel to this direction. The effect of anisotropy on the shear strength of rock has been researched over the last few decades. McCabe and Koerner investigated the relationship between the anisotropy of mica schist samples and the shear strength parameters of rock [130]. The Mohr-Coulomb criterion was used to assess the relationship between rock anisotropy, cohesion, internal friction, and shear strength. The results indicate that the shear intensity value varies with the angle of foliation. The maximum and minimum values for shear strength were recorded when the foliation angle was $\beta=30^{\circ}, \beta=70^{\circ}$, and $\beta=50-59^{\circ}$. Furthermore, increasing the degree of foliation and the size of the mica flake decreased cohesion and the internal friction angle. Strength anisotropy remains important in the presence of confined conditions, as evidenced by a large number of triaxial tests on Delabole slates and Himalayan schists $[36,131]$ With increasing confining pressures, strength anisotropy decreases [132]. Ramamurthy et al. investigated the anisotropy behavior of phyllites [32]. The compressive strength of phyllites increases non-linearly at all orientation angles of rock anisotropy. The results indicate that the variations in cohesion with $\sigma_{3}$ at a particular $\beta$ are exactly the opposite of those in internal friction. For example, cohesion increases and internal friction decreases when $\sigma_{3}$ increases, and vice versa. Moreover, the variation in cohesion with $\sigma_{3}$ at a particular $\beta$ is significant, whereas the variation in internal friction is insignificant. Nasseri et al. noted that maximum and minimum strength values for quartzitic, chlorite, and quartz mica schists are observed at $\beta=90^{\circ}$ and $\beta=30-45^{\circ}$, respectively [126]. Maximum strength values for quartzitic and chlorite schists were observed at $\beta=90^{\circ}$ throughout the range of confining pressures. The minimum strength is commonly $30^{\circ}$ to $45^{\circ}$. However, quartzitic schist showed a $30 \%$ strength improvement at $\beta=30^{\circ}$ due to confinement. For chlorite schist, this improvement was $15 \%$, and for quartz mica schist it was $10 \%$. Heng et al. studied the effects of anisotropy orientations on the shear strength and failure mechanisms of some shale samples [37]. The results demonstrate that the angle between the bedding planes and the coring orientation is an important factor in strength, cohesion, and internal friction, and the maximum and minimum values of shear strength were reached at $\beta=60^{\circ}$ and $\beta=0^{\circ}$, respectively.

The foliation angle in anisotropic rock strongly affects the geomechanical parameters, and rock strength is a crucial aspect in the design of rock structures. The representative 
failure criteria are necessary for the analysis of these structures' stability. Therefore, the failure criteria of anisotropic rock will be discussed in the next section.

In summary, our review indicates that the mechanical behavior of a rock is predominantly determined by textural characteristics, such as grain size, shape and packing density (collectively expressed as "texture coefficient"), rather than by its mineral composition. Such information is generally readily available through routine geological and petrographic descriptions. Single and multivariable regressions between geomechanical parameters and texture were introduced. These regressions were developed in different but specific geological settings and rock types, and therefore cannot be universally applied to different types of rock that have contrasting mineral assemblages. A model that is applicable to a wide range of rock types and geological settings needs to be developed. Another possible future avenue for research would be to compare empirical methods with other methods, such as machine learning.

\section{Failure Criteria of Anisotropic Rocks}

Many constitutive models, as well as failure criteria, that refer to rock behavior under loading, are associated with rock strength anisotropy. A failure criterion can be defined according to Ambrose: "A Failure criterion is an equation that defines, either implicitly or explicitly, the value of the maximum principal stress that will be necessary in order to cause the rock to fail, which in the case of brittle behavior can be interpreted as causing the rock to break along one or more failure planes." [133] Each criterion has a few constants that must be calculated by a study of regression test results. The studies indicate that sedimentary and metamorphic rocks, such as shale, slate, gneiss, schist, and marble, show an intense anisotropy of strength $[128,134]$. This also leads to a non-linear strength response due to the dependence of rock strength on direction [33].

The assessment of the anisotropic strength behavior of different rock forms has been a difficult challenge for rock mechanical and geological engineers over the last few decades. Many failure criteria have been established as a result of these experiments, intended to predict the behavior of anisotropic rocks under loading. Most of the introduced anisotropic rock failure standards were classified in 1998 by Duveau et al. [135]. Ambrose then added the criteria that were developed in 2014 (Table 20) [133]. The failure criteria are often split into continuous and discontinuous types. The first group of criteria is called the mathematical continuous approach. A continuous body and a continuous variation in strength are presumed in these criteria. The mathematical methodology is used to define the strength anisotropy of the material and the types of material symmetries. Hill proposed one of the first anisotropic criteria for frictionless materials by extending the von Mises (1928) isotropic theory [136]. In 1966, Goldenblat and Kopnov suggested a general approach [137]. These authors proposed using tensor strengths in different orders to consider anisotropy. By modifying the Hill criterion, Pariseau proposed a commonly used criterion for geological materials that accounts for the strength difference between tensile and compressive loading, as well as the strength's dependence on the mean stress [138]. Tsai and Wu formulated failure criteria using first- and second-order strength tensors [139]. Boehler and Sawczuk in 1970 and 1977, and Boehler in 1975, established a systematic and general approach, within the framework of the theory of invariant tonsorial functions [140-142]. Relevant failure criteria for rock materials and composites have also been suggested [143,144]. Generalizations of the Mohr-Coulomb and von Mises isotropic failure criteria to orthotropic and transversely isotropic media can be found in Boehler's study [142]. Cazacu expanded the Stassi isotropic criteria to construct a new invariant failure criterion [145]. The second group of criteria is named the empirical continuous models. Strength anisotropy is simply described by the determination of variation laws as a function of the loading orientations of some material parameters used in the anisotropic criterion. Such laws of variance are entirely observational and are calibrated using basic laboratory experiments. These models are devoid of any direct physical or mathematical background. The variable cohesion theory, which was suggested by Jaeger in 1960, is one of the most representative criteria of 
this type [146]. This theory extended the Mohr-Coulomb failure criterion by using variable material cohesion with the loading orientation and a constant value of the friction. McLamore and Gray suggested a simple form of this criterion, and proposed a variation in the friction coefficient similar to that in the cohesion [147]. Single et al. and Ramamurthy et al. suggested a modification to the McLamore and Gray criteria using a non-linear form of the failure envelope in the Mohr plane [148,149]. In addition to the first two classes of criteria, the third set of criteria, known as the "discontinuous vulnerability plane-based" models, was established. Theories in this field have discussed how physical mechanisms contribute to failure processes. The fundamental idea is that the failure of an anisotropic body is caused by either bedding plane or rock matrix fractures. The single plane-of-weakness theory, which was suggested by Jaeger in 1960, is the most representative model of this group [146]. Other criteria were proposed (Walsh and Brace in 1964; Hoek in 1964 and 1983; Hoek and Brown in 1980) by considering the planes of weakness, as well as an extension of the modified Griffith theory [150-154]. A new theory was also recently proposed by Duveau et al., who introduced the use of the Barton criterion for sliding along schistosity planes [135]. The typical discontinuous criteria of anisotropic rocks in the current study are extracted from the literature, and will be briefly discussed. However, continuous models are beyond the objectives of this paper. Readers are referred to the suggested literature for additional information.

Table 20. Classification of widely used anisotropic failure criteria (Adapted from Ambrose [133]. The mentioned references in the table are from [155-179]).

\begin{tabular}{|c|c|c|}
\hline \multicolumn{2}{|c|}{ Continuous Criteria } & \multirow{2}{*}{ Discontinuous Criteria } \\
\hline Mathematical Approach & Empirical Approach & \\
\hline \multicolumn{3}{|l|}{ Von Mises (1928) } \\
\hline \multicolumn{3}{|l|}{ Hill (1948) } \\
\hline \multicolumn{3}{|l|}{ Olszak and Urbanowicz (1956) } \\
\hline \multicolumn{3}{|l|}{ Goldenblat (1962) } \\
\hline \multicolumn{3}{|l|}{ Goldenblat and Kopnov (1966) } \\
\hline Pariseau (1968) & Jaeger (variable cohesive strength & theory) $(1960,1964)$ \\
\hline \multicolumn{3}{|l|}{ Boehler and Sawczuk $(1970,1977)$} \\
\hline Tsa and $\mathrm{Wu}(1971)$ & Mclamore and Gray (1967) & Murrell (1965) \\
\hline \multicolumn{3}{|c|}{ Ramamurthy, Rao, and Singh (1998) } \\
\hline \multicolumn{3}{|l|}{ DafaliaS $(1979,1987)$} \\
\hline \multicolumn{3}{|r|}{ Ladanyi and Archambault (1972) } \\
\hline \multicolumn{3}{|l|}{ Nova and Sacchi (1979) } \\
\hline \multicolumn{3}{|r|}{ Hoek and Brown (1980) } \\
\hline \multicolumn{3}{|c|}{ Tien, Kuo, and Juang (2006) } \\
\hline \multicolumn{3}{|c|}{ Tiwari and Rao (2007) } \\
\hline \multicolumn{3}{|l|}{ Cazacu and Cristescu (1995) } \\
\hline \multicolumn{3}{|l|}{ Cazacu and Cristescu (1999) } \\
\hline \multicolumn{3}{|l|}{ Kusabuka et al. (1999) } \\
\hline \multirow{2}{*}{\multicolumn{3}{|c|}{$\begin{array}{c}\text { Pietruszczak and } \mathrm{Mroz} \\
(2001)\end{array}$}} \\
\hline & & \\
\hline \multicolumn{3}{|l|}{ Lee and Pietruszczak (2008) } \\
\hline \multicolumn{3}{|l|}{ Mroz and Maciejewski } \\
\hline$(2011)$ & & \\
\hline
\end{tabular}

Jaeger's single plane-of-weakness theory, which is the starting point of the discontinuous method, is regarded as the first attempt [146]. Two distinct failure modes, namely, failure along the discontinuity and failure across intact materials, were presumed to exist within this criterion (Figure 6) [180]. The standard Mohr-Coulomb criterion is applied to characterize the failure of bedding planes and the rock matrix in this theory, but it employs two different sets of material constants. This criterion provides good results for slightly stratified rocks. However, the results are often undesirable in the case of extremely stratified materials. The main explanation is that the bedding planes behave similarly to 
rock joints, and the Mohr-Coulomb criterion is unsuitable for modeling the failures of such discontinuities. A plane of weakness that forms an angle $\beta$ with the axis of the main principal stress is described by this theory. The angle " $\beta$ " is defined as the "orientation angle". The UCS envelope represents the variation in failure stress corresponding to the orientation angle.

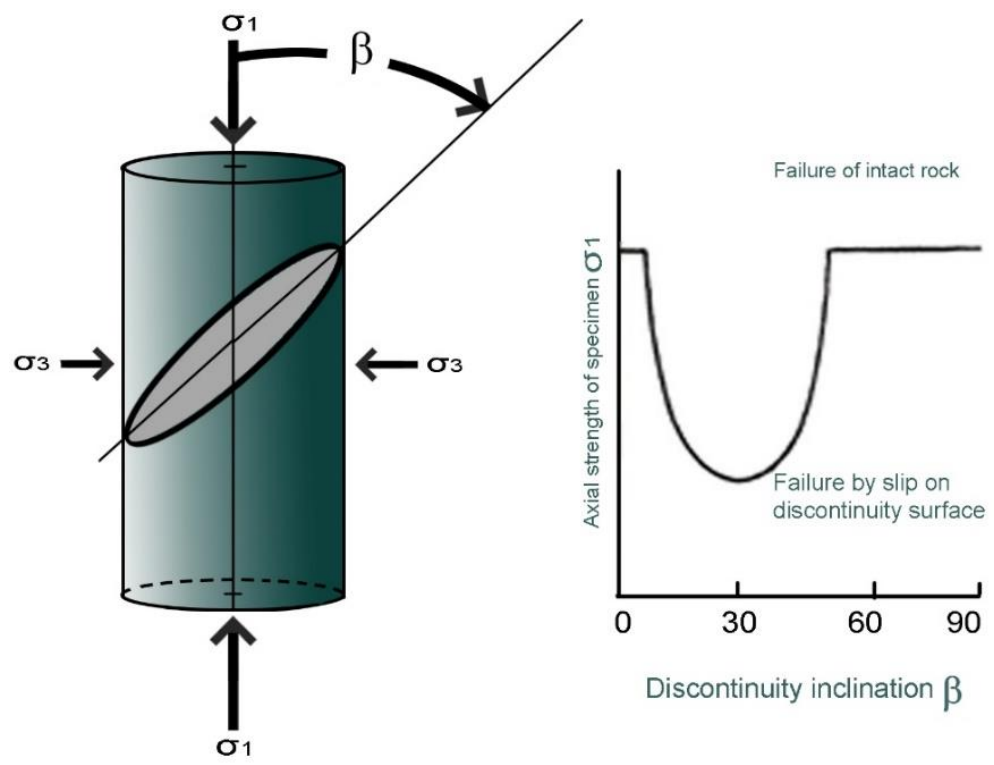

Figure 6. Single plane-of-weakness theory (reproduced from Saroglou and Tsiambaos [180]).

When sliding along discontinuities is prevented, Jaeger's original criterion can preserve rock as an isotropic material by considering four parameters (Figure 7a). The compression strength is the same when using Jaeger's criteria at $\beta=0^{\circ}$ and $90^{\circ}$. However, experimental data have revealed that the maximal strength in certain rocks exists at $\beta=0^{\circ}$, while that in other rocks occurs at $\beta=90^{\circ}$. Two additional parameters have been added by other researchers to Jaeger's criterion to justify the discrepancy (e.g., Duveau et al. replaced the Mohr-Coulomb criterion with a non-linear model to express the strength along discontinuity (Figure $7 b)$ ) $[135,181]$. Table 21 lists the material constants included in the modified and initial criteria.
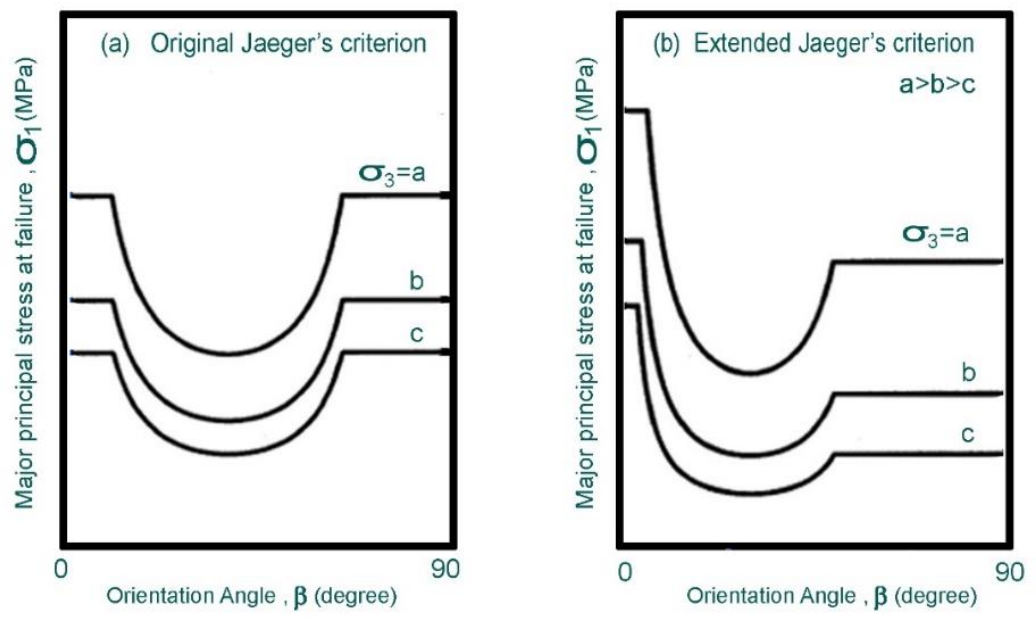

Figure 7. Diagram of strength variation versus $\beta$ : (a) original Jaeger's criterion; (b) extended Jaeger's criterion (Adapted from Tien and Kuo [181]). 
Table 21. Material constants included in the initial and modified criteria.

\begin{tabular}{ccc}
\hline Criteria & Jaeger Criterion & Modified Criterion \\
\hline Constant parameters & $\mathrm{C}_{0}, \tan \phi_{0}, \mathrm{C}_{90}, \tan \phi_{90}, C^{\prime}, \tan \phi^{\prime}$ & $\mathrm{C}_{0}, \tan \phi_{0}, \mathrm{C}_{90}, \tan \phi_{90}, C^{\prime}, \tan \phi^{\prime}, \mathrm{a}, \mathrm{b}, \sigma_{c 0}$ \\
\hline
\end{tabular}

Horino and Ellickson suggested a method for calculating strength based on the Coulomb strength criterion [182]. This criterion is written as Equation (4).

$$
\frac{\sigma_{1 f}}{\sigma_{1}}=\left[\frac{\left(1+\sigma_{\mathrm{s}}^{2}\right)^{2}-\mu_{\mathrm{s}}}{\operatorname{Sin} 2 \beta-\mu_{\mathrm{f}}(1-\operatorname{Cos} 2 \beta)}\right]
$$

where $\mu_{\mathrm{s}}$ is the slope of the Mohr rupture envelope at low stress levels, $\mu_{\mathrm{f}}$ is the coefficient of internal friction, and $\beta$ is the angle of anisotropy to the vertical. These parameters can be determined from the Mohr criterion for the material and the plane-of-weakness by a conventional triaxial test.

The failure of anisotropic rocks under confining pressure was discussed by Jaeger and Cook [183]. Equation (5) explains the UCS of a sample with a weak plane, which is identified by cohesion $C_{j}$ and friction angle $\phi$.

$$
\sigma_{1} \beta=\sigma_{3}+\frac{2\left[C_{j}+\sigma_{3} \tan \left(\phi_{j}\right]\right.}{\left[1-\tan \left(\phi_{j}\right) \tan (\beta)\right] \operatorname{Sin}(2 \beta)} .
$$

As mentioned for the single weakness plane theory (Jaeger's criterion), this theory is sufficient for predicting strength when the rock behaves anisotropically due to the existence of a single plane of weakness. However, the theory does not properly explain the strength behavior of intact rocks with intrinsic anisotropy due to the presence of bedding or foliation, as in the case of siltstones, schists, and gneisses. Consequently, the Hoek-Brown failure criterion was developed in 1980 for assessing intact rock quality and rock mass strength in isotropic conditions, to help predict the strength of intact anisotropic rock. Hoek and Brown proposed an adjustment to the value of the analytical criterion's constants $\mathrm{m}$ and $\mathrm{s}$ based on the direction of the foliation plane relative to the principal loading axis, $\beta$ [153]. This criterion is defined as Equation (6):

$$
\sigma_{1}=\sigma_{3}+\sigma_{\mathrm{ci}}+\left(\mathrm{m} \frac{\sigma_{3}}{\sigma_{\mathrm{ci}}}+\mathrm{S}\right)^{\alpha},
$$

where $\sigma_{3}$ is the minor principal stress, $\sigma_{1}$ is the major principal stress, $\sigma_{\mathrm{c} i}$ is the uniaxial compressive strength, and $\mathrm{m}, \mathrm{s}$, and $\alpha$ are material constants; $\mathrm{m}$ is equal to $\mathrm{m}_{\mathrm{i}}, \alpha=0.5$, and $\mathrm{s}=1$ when the rock is intact.

Saroglou and Siambaos introduced a new parameter $\left(\mathrm{k}_{\beta}\right)$ to the Hoek and Brown criterion for the influence of strength anisotropy [180]. Consequently, the quality of intact anisotropic rock under loading in various planes of anisotropy can be calculated. This criterion is defined as in Equation (7):

$$
\sigma_{1}=\sigma_{3}+\sigma_{\mathcal{c} \beta}+\left(K_{\beta m_{i}} \frac{\sigma_{3}}{\sigma_{c \beta}}+1\right)^{0.5}
$$

where $\sigma_{c \beta}$ is the uniaxial compressive strength at an angle of loading $\beta$, and $\mathrm{k}_{\beta}$ is the parameter describing the anisotropy effect. Based on the anisotropic index $\left(\alpha_{\beta}\right)$, this model describes the triaxial strength behavior of rocks. It is necessary in the model to estimate the uniaxial compressive strength at a given angle. Consequently, a mathematical equation is 
developed to predict the variation in the uniaxial compressive strength of anisotropic rocks. The model is as follows:

$$
\sigma_{1}=\sigma_{3}+\sigma_{\mathrm{c} \beta}+\left(\mathrm{m}_{\mathrm{i}} \frac{\sigma_{3}}{\sigma_{\mathrm{ci}}}+\mathrm{S}\right)^{\alpha_{\beta}}
$$

where $\alpha_{\beta}$ is the anisotropic index that determines the curvature of the failure envelope. In order to apply the failure criterion, the UCS $\left(\sigma_{c \beta}\right)$ and anisotropic index $\left(\alpha_{\beta}\right)$ need to be known for the given orientation $\beta$ (Equations (9) and (10)), as well as the strength parameter $\mathrm{m}_{\mathrm{i}}$.

$$
\begin{gathered}
\sigma_{\mathrm{c} \beta}=\sigma_{\mathrm{c} 0}-\left(\sigma_{\mathrm{c} 0}-\sigma_{\mathrm{cmin}}\right)\left[\operatorname{Sin}\left(\frac{\beta}{\theta} 90^{\circ}\right)\right]^{\mathrm{m}} 0^{\circ} \leq \beta \leq \theta \\
\sigma_{\mathrm{c} \beta}=\sigma_{\mathrm{c} 90}-\left(\sigma_{\mathrm{c} 90}-\sigma_{\mathrm{cmin}}\right)\left[\operatorname{Cos}\left(\frac{\beta-\theta}{90^{\circ}-\theta} 90\right)\right]^{\mathrm{n}} \theta<\beta \leq 90
\end{gathered}
$$

where $\sigma_{\mathrm{c} \beta}$ is the uniaxial compressive strength of anisotropic rocks, $\sigma_{\mathrm{cmin}}$ is the minimum value of uniaxial compressive strength, and $\mathrm{m}$ and $\mathrm{n}$ are constants. As regards model verification, they also consequently presented a "general" relationship between $\alpha_{\beta}$ and $\sigma_{\mathrm{c} \beta}$.

$$
\alpha_{\beta}=1.5-\left(\frac{\sigma_{c \beta}}{\sigma_{c i}}\right)^{b}
$$

Each of these approaches, however, requires a range of tests and/or a lot of curvefitting. In 1948, Hill proposed a substantially general criterion for anisotropic materials that can be expressed as a quadratic function [136]. As such, it extends von Mises's isotropic criterion. Von Mises and Hill's criteria assume the strength of materials to be independent of hydrostatic stresses, and they may be suitable for metals and composite materials, but may not be applicable directly to geological materials because most geological materials are dependent on hydrostatic stresses in terms of their strength behavior. Taking the effects of hydrostatic stresses into account, Pariseau and Cazacu et al. extended Hill's criteria [138,145]. These are applicable to real 3D stress cases; they can be numerically implemented and express the strength in relation to stress invariance. A generalized failure criterion for transversely isotropic rocks has been proposed by Nova [184,185]. According to Hill and Nova, strength continuously varies with orientation angle. The continuous model is referred to herein. It is, however, inapplicable for shoulder and undulatory rocks, and especially for rocks that have discontinuities in their structures.

Tien and Kuo presented a new failure criterion for transversely isotropic rocks [181]. Two distinct failure modes are considered: failure occurs by sliding along the discontinuities, and a non-sliding mode wherein the failure is controlled by the rock material (Equation (12)). The developed criterion comprises seven material parameters: cohesion and the

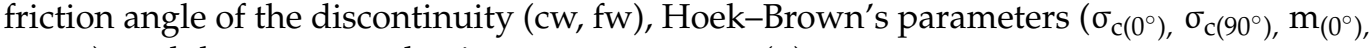
$\left.\mathrm{m}_{\left(90^{\circ}\right)}\right)$, and the transversal anisotropy parameter $(\mathrm{n})$.

$$
\frac{S_{1(\beta)}}{S_{1\left(90^{\circ}\right)}}=\frac{\sigma_{1(\beta)}-\sigma_{3}}{\sigma_{1\left(90^{\circ}\right)}-\sigma_{3}}=\frac{K}{\operatorname{Cos}^{4} \beta+K \operatorname{Sin}^{4} \beta+2 n \operatorname{Sin}^{2} \beta \operatorname{Cos}^{2} \beta}
$$

where $\mathrm{S}_{1(\beta)}=\mathrm{E}_{\mathrm{y} \varepsilon \mathrm{yf}}, \mathrm{S}_{1\left(90^{\circ}\right)}=\mathrm{E}_{\left(90^{\circ}\right) \varepsilon \mathrm{yf}}$, and $\mathrm{K}=\frac{\mathrm{E}_{\left(0^{\circ}\right)}}{\mathrm{E}_{\left(90^{\circ}\right)}}=\frac{\mathrm{S}_{1\left(0^{\circ}\right)}}{\mathrm{S}_{1\left(90^{\circ}\right)}}$.

Rafiai proposed a new criterion for the prediction of intact rock and rock mass failure under a polyaxial state of stresses (Equation (13)) [186]. According to the following relationship between effective principal stresses, rock failure in triaxial loading conditions can be demonstrated empirically:

$$
\frac{\sigma_{1}}{\sigma_{\mathrm{c}}}=\frac{\sigma_{3}}{\sigma_{\mathrm{c}}}+\frac{1+\mathrm{A}\left(\frac{\sigma_{3}}{\sigma_{\mathrm{c}}}\right)}{1+\mathrm{B}\left(\frac{\sigma_{3}}{\sigma_{\mathrm{c}}}\right)}-\mathrm{r}
$$


where $\sigma_{\mathrm{c}}$ is the UCS of intact rock, and A and B are dimensionless constants that depend on the rock properties $(\mathrm{A} \leq \mathrm{B} \leq 0)$. The parameter $\mathrm{r}$ indicates how much the rock mass has been fractured according to its strength. For intact rock, $r=0$; for heavily jointed rock masses, $\mathrm{r}=1$.

The other proposed criterion for rock failure in the polyaxial state of stresses can be expressed by the following relation between effective principal stresses.

$$
\frac{\sigma_{1}}{\sigma_{\mathrm{c}}}=\frac{\sigma_{1}^{\operatorname{trx}}}{\sigma_{\mathrm{c}}}+\sqrt{\mathrm{C} \frac{\sigma_{2}-\sigma_{3}}{\sigma_{1}^{\operatorname{trx}}}} \exp f()\left(-\frac{\sigma_{2}-\mathrm{D} \sigma_{3}}{\sigma_{1}^{\operatorname{trx}}}\right)
$$

where $C$ and $D$ are constants, and $\sigma_{1}^{\operatorname{trx}}$ is the rock strength in the triaxial state of stresses $\left(\sigma_{2}=\sigma_{3}\right)$, as presented below.

$$
\frac{\sigma_{1}^{\operatorname{trx}}}{\sigma_{\mathrm{c}}}=\frac{\sigma_{3}}{\sigma_{\mathrm{c}}}+\frac{1+\mathrm{A}\left(\frac{\sigma_{3}}{\sigma_{\mathrm{c}}}\right)}{1+\mathrm{B}\left(\frac{\sigma_{3}}{\sigma_{\mathrm{c}}}\right)}-\mathrm{r}
$$

Saeidi et al. proposed a modified failure criterion to determine the strength of transversely isotropic rocks by considering the rock failure criteria proposed by Rafiai for the triaxial failure criterion [134]. An index, which can be measured as a strength reduction parameter due to rock strength anisotropy, was obtained through the modification process. The modified criterion is as follows:

$$
\sigma_{1}=\sigma_{3}+\sigma_{\mathrm{c} \beta}\left[\frac{1+\mathrm{A}\left(\frac{\sigma_{3}}{\sigma_{\mathrm{c} \beta}}\right)}{\alpha+\mathrm{B}\left(\frac{\sigma_{3}}{\sigma_{\mathrm{c} \beta}}\right)}\right],
$$

where $\sigma_{\mathrm{c} \beta}$ is the UCS of transversely intact isotropic rock at anisotropy orientation, $\alpha$ is the strength reduction parameter related to the rock anisotropy, and A and B are constant parameters. Several transversely isotropic rocks were compared using the modified HoekBrown and Ramamurthy criteria. Consequently, the modified failure criteria proposed can be used to predict the strength of transversely isotropic rocks.

In summary, rocks fail in a variety of ways, either by the initiation and propagation of microcracks, or by the total structural breakdown that occurs as many cracks coalesce. In both cases, the processes are extremely complex and cannot be easily characterized by simplified models. The Mohr-Coulomb criterion describes the relationship between shear stress and normal stress at failure. According to the Hoek-Brown criterion, a best fit is found by plotting strength values in $\sigma_{1}-\sigma_{3}$ space. By means of experimental tests and numerical simulations, models and equations, the rock characteristic used in these criteria have to be determined as functions of rock texture parameters. More precisely, the effect of rock texture on the rock characteristics of each failure criterion has to be determined. This study could help engineers to modify the mentioned criteria as functions of rock texture in order to apply them to different rock structures, such as the surfaces of underground structures.

\section{Discussion}

The mechanical and physical characteristics of rocks are important to engineering applications. Such properties can be influenced by the rock's petrographic characteristics, including its composition and texture, which result from the environment of formation (e.g., sedimentation, diagenesis, metamorphism, and weathering) [187]. The current review indicates that mineral composition is the most dominant feature in rock strength. The amount of quartz and feldspar can affect its strength. A high percentage of quartz strengthens the rocks, while the presence of feldspar can reduce strength, especially if the feldspar is present as phenocrysts. However, feldspar is susceptible to alteration (hydrothermal or weathering), and further reduces the strength of the rocks once degraded to a secondary 
mineral. In addition, rock strength can be reduced by the presence of mica minerals, a common component of fine-grained sedimentary rocks and altered volcanic and magmatic rocks. The presence of mica minerals diminishes the rock strength. Weathering grade also affects the strength of the rock, despite its small size.

Anisotropy is the other essential factor that can affect rock strength. The minimum value is usually around $\beta=30^{\circ}$, based on the overall evaluation and interpretation of the experimental results, and the maximum failure strength is either $\theta=0^{\circ}$ or $\theta=90^{\circ}$. Anisotropic rocks become increasingly ductile as confining pressure is increased in triaxial tests. When anisotropic rocks are subjected to uniaxial and triaxial compression tests, the orientation of the loading and the confining pressure influence the failure modes. Two kinds of failure modes are distinguishable, namely: (1) sliding failure mode, where plane discontinuity is predominant, and (2) non-sliding failure mode, where the material strength dominates.

The third important parameter is grain size. The sizes of the pores are proportional to the grain size. These pores can reduce the strength of the rocks. The degree of interlocking in a granitic rock affects its strength. The presence of anhedral-subhedral grains will reduce rock strength. Meanwhile, euhedral grains can increase the strength because they are well-formed with sharp faces. Some researchers have argued that strength may not strongly depend on grain size, despite the correlations between mechanical properties and the sizes of mineral grains.

For the analysis of rock stability, it is necessary to apply a representative failure criterion. The strength of the rock is affected by its anisotropy; thus, the stability analysis of anisotropic rocks requires representative failure criteria. From a qualitative viewpoint, the two methods (continuous and discontinuous) use various hypotheses and techniques. An overall study of the mechanical behaviors of materials has revealed that mathematical continuous models offer a general and systematic method, using anisotropic strength tensors. These models have an invariant formulation considering the substance symmetry groups. Their calibration only requires a few laboratory experiments, and their numerical implementation is simple and reliable. However, the theoretical calibration procedure suggested in these models cannot be used in reality, because performing the necessary laboratory experiments is always difficult, and it is often important to employ a numerical optimal fitting system. Moreover, in strongly anisotropic rocks, such as schists, the discontinuous aspect of the transition from rock matrix failure to schistosity plane sliding is not captured by these models. Therefore, these models generally exhibit excessively smooth variations in material strength. However, these models can provide an excellent modeling of weakly anisotropic material failure behavior when the effects of weakness planes are not dominant. Ambrose showed that Pariseau's criterion is the most commonly used mathematical model [133]. Empirical continuous models provide a rudimentary adaptation of isotropic strength criteria to anisotropic materials by proposing empirical variation laws of model parameters with loading orientation. These models have a simple mathematical form, and can be easily determined via their parameters. However, the physical meanings of the empirical laws and the involved parameters remain unclear. In addition, a high number of laboratory tests is necessary to find reliable variation laws. These models have the same weaknesses as the statistical continuous models when used for a substance with strong bedding planes. The friction angle is generally assumed to be constant for this group, and the cohesion parameters are orientation-specific. Most equations are easy to construct and modify, and they are also straightforward to use. A comparison between mathematical and empirical criteria is represented in Table 22. 
Table 22. Mathematical and empirical continuous criteria $[133,135,188]$.

\begin{tabular}{|c|c|}
\hline Mathematical Continuous Criteria & Empirical Continuous Criteria \\
\hline Definition: & Definition: \\
\hline $\begin{array}{l}\text { The mathematical technique used to describe a material's } \\
\text { strength function, taking into account the type of symmetry } \\
\text { present in the material. From these criteria, constants } \\
\text { are obtained. }\end{array}$ & $\begin{array}{l}\text { By applying empirical laws defined by the variation in material } \\
\text { parameters considering loading orientation, it is possible to } \\
\text { describe anisotropic strength using the isotropic failure criterion. } \\
\text { Experimental data are used to determine the parameters. }\end{array}$ \\
\hline $\begin{array}{l}\text { Representative Criterion: } \\
\text { In the theory of frictionless materials, the main and first } \\
\text { criterion is Hill's principle, which is an extension of Von Mises' } \\
\text { isotropic theory. Pariseau in } 1968 \text { extended Hill's criterion for } \\
\text { cohesive-frictional materials similar to rocks. }\end{array}$ & $\begin{array}{l}\text { Representative Criterion: } \\
\text { Using variational cohesion as a function of loading orientation } \\
\text { and constant friction, Jaeger in } 1960 \text { proposed a modification of } \\
\text { the Mohr-Coulomb criterion. }\end{array}$ \\
\hline $\begin{array}{l}\text { Challenges: } \\
\text { (1) In order to determine the material constants, } \\
\text { experimentation should be conducted. } \\
\text { (2) Analyzing the physical behavior of the material or the tested } \\
\text { rocks gives each criterion its own perspective on anisotropy. }\end{array}$ & $\begin{array}{l}\text { Challenges: } \\
\text { (1) For such a criterion to be established, there must be a large } \\
\text { amount of experimental data and a curve-fitting procedure. } \\
\text { (2) The physical and mathematical bases of such criteria } \\
\text { are lacking. }\end{array}$ \\
\hline
\end{tabular}

In contrast to continuous models, the discontinuous model of the weakness plane reveals that material strength is inherently linked to the presence of bedding planes. The final material failure is due to two distinct mechanisms operating at the microscopic level: isotropic failure in the rock matrix and orientated failure along weakness planes. These models lead to simple and physical equations. Because of its clear physical meaning and high level of precision, this hypothesis is widely used in engineering. In addition, these models contain a small number of parameters, and their determination is generally easy. Thus, these models are well suited to strongly anisotropic materials.

Recently, research was conducted on the mechanism of failure. Zhixiang et al. concluded that after the peak of sub-instability, macroscopic instability occurs [189]. Moreover, sandstone samples under stress-seepage coupling exhibited peak strength and a deformation evolution law that was clearly affected by both confining pressure and stress-seepage coupling [190]. Zhang et al. in 2021 studied the permeability and energy evolution characteristics of deep sandstone [191]. According to a nonlinear growth exponential model, the permeability and the energy density dissipation of deep sandstone were both well correlated with input energy.

\section{Summary and Conclusions}

An assessment of the relationships between the mechanical and textural characteristics of rocks is crucial to a study seeking to obtain additional information regarding the behavior of the rock. This study presents the influence of mineral composition, grain size and shape, and anisotropy on the mechanical properties of rock. The main influence on the mechanical characteristics of the rock lies in the variations in the quartz and feldspar contents. Quartz and feldspar have high control in and influence over rock strength. The UCS and crack propagation are affected by opaque and altered minerals. The grain size and porosity play a significant role in mechanical properties, even more so than the mineral composition. Anisotropy in the rock has a strong effect on its mechanical properties. Many studies have attempted to establish a correlation between rock anisotropy and UCS parameters, and found that the strengths of various kinds of rocks depended on the degree of anisotropy and the directions of stresses. Moreover, the shear intensity value varies with the angle of foliation. As such, several failure criteria based on continuous and discontinuous criteria have been proposed to find the strength of anisotropic rocks. It is important that the anisotropic failure criterion is easy to use for a rock engineering designer, as well as being capable of predicting the strength of the rock. Because its parameters can be easily understood by engineers, Mohr-Coulomb's criterion tends to be used for isotropic rocks, while Jaeger's plane-of-weakness theory tends to be used for anisotropic rocks. 
Many questions remain unanswered, despite there being many studies available regarding the relationship between rock texture and the mechanical properties of the rock. An investigation into the following issues may be of interest in the future.

1. The model is extracted in different geological settings or rock types. However, the evidence is insufficient to obtain a precise regression analysis between geomechanical parameters of rock and rock texture characteristics. For example, most regression equations between minerals and rock strength are based on there being only one or two main minerals in the rock, and the influence of other significant minerals, even in low percentage, has not been fully explored. Thus, further attempts at the following aspects should be made.

2. The models, equations, and criteria should be developed to determine the effects of rock texture characteristics on the mechanical properties of rocks through experimental tests and numerical simulations. Moreover, these equations or criteria should be applied to different rock types from different origins to validate these models.

3. In the field of rock strength, the stability of the rock is also related to in situ stress conditions, excavation depth, rock texture, and hydrogeological conditions surrounding the excavation zone. Therefore, future studies should focus on the relationship between these parameters and the texture parameters of the rock. Considering these factors, the application of these techniques for the prediction of rock behavior will be straightforward and beneficial.

Author Contributions: Conceptualization, M.A., A.S., P.M.-L. and A.R.; methodology, M.A., A.S., P.M.-L. and A.R.; investigation, M.A., A.S., P.M.-L. and A.R.; writing-original draft preparation, M.A., A.S., P.M.-L. and A.R.; writing-review and editing, M.A., A.S., P.M.-L. and A.R.; visualization, M.A.; supervision, A.S., A.R., P.M.-L.; funding acquisition, M.A., A.S., P.M.-L. and A.R. All authors have read and agreed to the published version of the manuscript.

Funding: This research was funded by Natural Sciences and Engineering Research of Canada (NSERC) grant number [RDCPJ 520428-17].

Data Availability Statement: Not applicable.

Conflicts of Interest: The authors declare no conflict of interest.

\section{References}

1. Zhang, L. Engineering Properties of Rocks; Geo-Engineering Book Series; Hudson, J., Ed.; Elsevier: Amsterdam, The Netherlands, 2006; pp. 226-230.

2. Tapponnier, P.; Brace, W.F. Development of stress-induced microcracks in Westerly granite. Int. J. Rock Mech. Min. Sci. Geomech. 1976, 13, 103-112. [CrossRef]

3. Miskovsky, K.; Duarte, M.T.; Kou, S.Q.; Lindqvist, P.A. Influence of the mineralogical composition and textural properties on the quality of coarse aggregates. J. Mater. Eng. Perform. 2004, 2004. 13, 144-150. [CrossRef]

4. Saroglou, H.; Marinos, P.; Tsiambaos, G. The anisotropic nature of selected metamorphic rocks from Greece. J. South. Afr. Inst. Min. Metall. 2004, 104, 217-222.

5. Shakoor, A.; Bonelli, R.E. Relationship between petrographic characteristics, engineering index properties, and mechanical properties of selected sandstones. Bull. Assoc. Eng. Geol. 1991, 28, 55-71. [CrossRef]

6. Přikryl, R. Assessment of rock geomechanical quality by quantitative rock fabric coefficients: Limitations and possible source of misinterpretations. Eng. Geol. 2006, 87, 149-162. [CrossRef]

7. Sun, W.; Wang, L.; Wang, Y. Mechanical properties of rock materials with related to mineralogical characteristics and grain size through experimental investigation: A comprehensive review. Front. Struct. Civ. Eng. 2017, 11, 322-328. [CrossRef]

8. Song, Z.; Zhang, J. The effect of confining pressure on mechanical properties in coal and rock: Review and new insights. Arab. J. Geosci. 2021, 14, 1-22. [CrossRef]

9. Williams, H.; Turner, F.J.; Gilbert, C.M. Petrography: An Introduction to the Study of Rocks in Thin Section; W.H. Freeman and Company: San Francisco, CA, USA, 1982; pp. 12-41.

10. Schulz, B.; Sandmann, D.; Gilbricht, S. SEM-Based Automated Mineralogy and Its Application in Geo- and Material Sciences. Minerals 2020, 10, 1004. [CrossRef]

11. Kahn, J.S. The analysis and distribution of the properties of packing in sand-size sediments: 1 . On the measurement of packing in sandstones. J. Geol. 1956, 64, 385-395. [CrossRef] 
12. Dreyer, W. The Science of Rock Mechanics, Part 1: The Strength Properties of Rocks; Trance Tech Publications: Cleveland, OH, USA, 1973; p. 501.

13. Dobereiner, L.; Freitas, M.D. Geotechnical properties of weak sandstones. Geotechnique 1986, 36, 79-94. [CrossRef]

14. Krumbein, W.C. Measurement and geological significance of shape and roundness of sedimentary particles. J. Sediment. Res. 1941, 11, 64-72. [CrossRef]

15. Wadell, H. Volume, shape, and roundness of rock particles. J. Geol. 1932, 40, 443-451. [CrossRef]

16. Howarth, D.F.; Rowlands, J.C. Development of an index to quantify rock texture for qualitative assessment of intact rock properties. Geotech. Test. J. 1986, 9, 169-179.

17. Vutukuri, V.S.; Lama, R.D.; Saluja, S.S. Handbook on Mechanical Properties of Rocks, Testing Techniques and Results; Trans Technical Publications: Clausthal, Germany, 1974; p. 280.

18. Taylor, J.M. Pore-space reduction in sandstones. AAPG Bull. 1950, 34, 701-716.

19. Tsidzi, K.E.N. A quantitative petrofabric characterization of metamorphic rocks. Bull. Int. Assoc. Eng. Geol. 1986, 33, 3-12. [CrossRef]

20. Al-Harthi, A.A. Effect of planar structures on the anisotropy of Ranyah sandstone, Saudi Arabia. Eng. Geol. 1999, 50, 49-57. [CrossRef]

21. Bell, F.G. The physical and mechanical properties of the fell sandstones, Northumberland, England. Eng. Geol. 1987, 12, 1-29. [CrossRef]

22. Zorlu, K.; Ulusay, R.T.; Ocakoglu, F.; Gokceoglu, C.A.; Sonmez, H. Predicting intact rock properties of selected sandstones using petrographic thin-section data. Int. J. Rock Mech. Min. Sci. 2004, 41, 93-98. [CrossRef]

23. Cox, M.R.; Budhu, M. A practical approach to grain shape quantification. Eng. Geol. 2008, 96, 1-16. [CrossRef]

24. Ehrlich, R.; Weinberg, B. An exact method for characterization of grain shape. J. Sediment. Res. 1970, 40, $205-212$.

25. Beddow, J.K.; Vetter, A.F. The use of classifiers in morphological analysis of articulates. J. Powder Bulk Solids Technol. 1977, 1, 42-45.

26. Kaye, B.H. Review of new methods for characterize the shape and texture of fine particle. J. Powder Bulk Solids Technol. 1982, 6, $1-4$.

27. Howarth, D.F.; Rowlands, J.C. Quantitative assessment of rock texture and correlation with drillability and strength properties. Rock Mech. Rock Eng. 1987, 20, 57-85. [CrossRef]

28. Higgins, M.D. Quantitative Textural Measurements in Igneous and Metamorphic Petrology; Cambridge University Press: Cambridge, UK, 2006; pp. 7-9.

29. Hack, R.; Price, D. Quantification of weathering. Proc. Eng. Geol. Environ. 1997, 1, 145-150.

30. Matsukura, Y.; Hashizume, K.; Oguchi, C.T. Effect of microstructure and weathering on the strength anisotropy of porous rhyolite. Eng. Geol. 2002, 63, 39-47. [CrossRef]

31. Salager, S.; François, B.; Nuth, M.; Laloui, L. Constitutive analysis of the mechanical anisotropy of Opalinus Clay. Acta Geotech. 2013, 8, 137-154. [CrossRef]

32. Ramamurthy, T. Strength Modulus Responses of Anisotropic Rocks. Compressive Rock Eng. 1993, 1, $313-329$.

33. Tien, Y.M.; Kuo, M.C. A failure criterion for transversely isotropic rocks. Int. J. Rock Mech. Min. Sci. 2001, 38, 399-412. [CrossRef]

34. Ajalloeian, R.; Lashkaripour, G.R. Strength anisotropies in mudrocks. Bull. Eng. Geol. Environ. 2000, 59, 195-199. [CrossRef]

35. Behrestaghi, M.H.; Rao, K.S.; Ramamurthy, T. Engineering geological and geotechnical responses of schistose rocks from dam project areas in India. Eng. Geol. 1996, 44, 183-201. [CrossRef]

36. Nasseri, M.H.; Rao, K.S.; Ramamurthy, T. Anisotropic strength and deformational behavior of Himalayan schists. Int. J. Rock Mech. Min. Sci. 2003, 40, 3-23. [CrossRef]

37. Heng, S.; Guo, Y.; Yang, C.; Daemen, J.J.; Li, Z. Experimental and theoretical study of the anisotropic properties of shale. Int. J. Rock Mech. Min. Sci. 2015, 74, 58-68. [CrossRef]

38. Amadei, B. Importance of anisotropy when estimating and measuring in situ stresses in rock. Int. J. Rock Mech. Min. Sci. Geomech. 1996, 33, 293-325. [CrossRef]

39. Singh, J.; Ramamurthy, T.; Venkatappa, R.G. Strength anisotropies in rocks. Geo Tech. 1989, 19, 147-166.

40. ISRM. Rock Characterization, Testing and Monitoring, ISRM Suggested Methods; Pergamon Press: Oxford, UK, 1981.

41. Saroglou, H.; Tsiambaos, G. Classification of Anisotropic Rocks. In Proceedings of the 11th ISRM Congress, Lisbon, Portugal, 9-13 July 2007.

42. Tsidzi, K.E. The influence of foliation on point load strength anisotropy of foliated rocks. Eng. Geol. 1990, 29, 49-58. [CrossRef]

43. Franklin, J. Suggested method for determining Point Load Strength (revised version). Int. J. Rock Mech. 1985, 2, 51-60. [CrossRef]

44. Tsidzi, K.E. Propagation characteristics of ultrasonic waves in foliated rocks. Assoc. Eng. Geol. 1997, 56, $103-113$.

45. Onodera, T.F.; Asoka Kumara, H.M. Relation between texture and mechanical properties of crystalline rocks. Bull. Int. Assoc. Eng. Geol. 1980, 22, 173-177. 
46. Y1lmaz, N.G.; Goktan, R.M.; Kibici, Y. An investigation of the petrographic and physico-mechanical properties of true granites influencing diamond tool wear performance, and development of a new wear index. Wear 2011, 271, 960-969. [CrossRef]

47. Merriam, R.; Rieke, H.H., III; Kim, Y.C. Tensile strength related to mineralogy and texture of some granitic rocks. Eng. Geol. 1970, 4, 155-160. [CrossRef]

48. Hornby, B.E.; Schwartz, L.M.; Hudson, J.A. Anisotropic effective-medium modeling of the elastic properties of shales. Geophysics 1994, 59, 1570-1583. [CrossRef]

49. Gupta, A.S.; Rao, K.S. Weathering effects on the strength and deformational behaviour of crystalline rocks under uniaxial compression state. Eng. Geol. 2000, 56, 257-274. [CrossRef]

50. Mondol, N.H.; Jahren, J.; Bjørlykke, K.; Brevik, I. Elastic properties of clay minerals. Lead. Edge 2008, 27, 758-770. [CrossRef]

51. Sousa, L.M. The influence of the characteristics of quartz and mineral deterioration on the strength of granitic dimensional stones. Environ. Earth Sci. 2013, 69, 1333-1346. [CrossRef]

52. Yusof, N.Q.; Zabidi, H. Correlation of mineralogical and textural characteristics with engineering properties of granitic rock from Hulu Langat, Selangor. Procedia Chem. 2016, 19, 975-980. [CrossRef]

53. An, W.B.; Wang, L.; Chen, H. Mechanical properties of weathered feldspar sandstone after experiencing dry-wet cycles. Adv. Mater. Sci. Eng. 2020, 2020, 1-15. [CrossRef]

54. Feng, X.T.; Zhao, J.; Wang, Z.; Yang, C.; Han, Q.; Zheng, Z. Effects of high differential stress and mineral properties on deformation and failure mechanism of hard rocks. Can. Geotech. J. 2021, 58, 411-426. [CrossRef]

55. Ma, Z.; Gamage, R.P.; Zhang, C. Mechanical properties of $\alpha$-quartz using nanoindentation tests and molecular dynamics simulations. Int. J. Rock Mech. Min. Sci. 2021, 147, 104878. [CrossRef]

56. Lu, Y.; Li, C.; He, Z.; Gao, M.; Zhang, R.; Li, C.; Xie, H. Variations in the physical and mechanical properties of rocks from different depths in the Songliao Basin under uniaxial compression conditions. Geomech. Geophys. Geo-Energy Geo-Resour. 2020, 6, 1-14. [CrossRef]

57. Ündül, Ö. Assessment of mineralogical and petrographic factors affecting petro-physical properties, strength and cracking processes of volcanic rocks. Eng. Geol. 2016, 210, 10-22. [CrossRef]

58. Orhan, M.; Işık, N.S.; Topal, T.A.; Özer, M.U.S. Effect of weathering on the geomechanical properties of andesite, Ankara-Turkey. Environ. Geol. 2006, 50, 85-100. [CrossRef]

59. Lundqvist, S.; Göransson, M. Evaluation and interpretation of microscopic parameters vs. mechanical properties of Precambrian rocks from the Stockholm region, Sweden. Proc. Eighth Euroseminar Microsc. Appl. Build. Mater. 2001, 11, 13-20.

60. Ulusay, R.; Türeli, K.; Ider, M.H. Prediction of engineering properties of a selected litharenite sandstone from its petrographic characteristics using correlation and multivariate statistical techniques. Eng. Geol. 1994, 38, 135-157. [CrossRef]

61. Hugman, R.H.; Friedman, M. Effects of texture and composition on mechanical behavior of experimentally deformed carbonate rocks. AAPG Bull. 1979, 63, 1478-1489.

62. Arel, E.; Tugrul, A. Weathering and its relation to geomechanical properties of Cavusbasi granitic rocks in northwestern Turkey. Bull. Eng. Geol. Environ. 2001, 60, 123-133.

63. Gu, R.; Fang, Y. Experiment study on effects of mineral composition on rheological characteristics of soft clayey soil. Rock Soil Mech. 2007, 28, 26-81.

64. Marques, E.A.; Barroso, E.V.; Menezes Filho, A.P.; Vargas, E.A., Jr. Weathering zones on metamorphic rocks from Rio de Janeiro-Physical, mineralogical and geomechanical characterization. Eng. Geol. 2010, 111, 1-18. [CrossRef]

65. Fereidooni, D. Determination of the geotechnical characteristics of hornfelsic rocks with a particular emphasis on the correlation between physical and mechanical properties. Rock Mech. Rock Eng. 2016, 49, 2595-2608. [CrossRef]

66. Chapagain, Y.P.; Sapkota, S.; Ghale, D.B.; Bohara, N.B.; Duwal, N.; Bhattarai, J. A case study on mineralogy and physicomechanical properties of commercial bricks produced in Nepal. SN Appl. Sci. 2020, 2, 1-14. [CrossRef]

67. Ahmad, T.; Rizwan, M.; Hussain, Z.; Ullah, S.; Ali, Z.; Khan, A.; Khan, H.A. mineralogical and Textural influence on physicomechanical properties of selected granitoids from Besham Syntaxis, Northern Pakistan. Acta Geodyn. Geomater 2021, 18, 347-362. [CrossRef]

68. Li, Q.; Li, J.; Duan, L.; Tan, S. Prediction of rock abrasivity and hardness from mineral composition. Int. J. Rock Mech. Min. Sci. 2021, 140, 46-58. [CrossRef]

69. Hemmati, A.; Ghafoori, M.; Moomivand, H.; Lashkaripour, G.R. The effect of mineralogy and textural characteristics on the strength of crystalline igneous rocks using image-based textural quantification. Eng. Geol. 2020, 266, 54-67. [CrossRef]

70. Wyering, L.D.; Villeneuve, M.C.; Wallis, I.C.; Siratovich, P.A.; Kennedy, B.M.; Gravley, D.M.; Cant, J.L. Mechanical and physical properties of hydrothermally altered rocks, Taupo Volcanic Zone, New Zealand. J. Volcanol. Geotherm. Res. 2014, 288, 76-93. [CrossRef]

71. Tang, A.M.; Cui, Y.J. Effects of mineralogy on thermo-hydro-mechanical parameters of MX80 bentonite. J. Rock Mech. Geotech. Eng. 2010, 2, 91-96. 
72. Pellegrino, A.; Prestininzi, A. Impact of weathering on the geomechanical properties of rocks along thermal-metamorphic contact belts and morpho-evolutionary processes: The deep-seated gravitational slope deformations of Mt. Granieri-Salincriti (Calabria-Italy). Geomorphology 2007, 87, 176-195. [CrossRef]

73. Bell, F.G.; Lindsay, P. The petrographic and geomechanical properties of some sandstones from the Newspaper Member of the Natal Group near Durban, South Africa. Eng. Geol. 1999. 53, 57-81. [CrossRef]

74. Tuğrul, A.; Zarif, I.H. Correlation of mineralogical and textural characteristics with engineering properties of selected granitic rocks from Turkey. Eng. Geol. 1999, 51, 303-317. [CrossRef]

75. Ward, C.R.; Nunt-Jaruwong, S.; Swanson, J. Use of marmineralogical analysis in geotechnical assessment of rock strata for coal mining. Int. J. Coal Geol. 2005, 64, 156-171. [CrossRef]

76. Brunhoeber, O.M.; Arakkal, D.; Ji, R.; Miletić, M.; Beckingham, L.E. Impact of mineral composition and distribution on the mechanical properties of porous media. E3S Web Conf. 2020, 205, 02006. [CrossRef]

77. Wang, Y.; Sun, J.; Liang, Z.; Huang, S.; Wang, Y. Experimental Study on the Mechanical Properties of Triaxial Compression of White Sandstone under the Coupling Action of Chemical Corrosion and Temperature. IOP Conf. Ser. Earth Environ. Sci. 2021, 692, 123-135. [CrossRef]

78. Han, Q.; Gao, Y.; Zhang, Y. Experimental Study of Size Effects on the Deformation Strength and Failure Characteristics of Hard Rocks under True Triaxial Compression. Adv. Civ. Eng. 2021, 1, 1-15. [CrossRef]

79. Ajalloeian, R.; Jamshidi, A.; Khorasani, R. Evaluating the Effects of Mineral Grain Size and Mineralogical Composition on the Correlated Equations Between Strength and Schmidt Hardness of Granitic Rocks. Geotech. Geol. Eng. 2021, 4, 1-11. [CrossRef]

80. Strauhal, T.; Zangerl, C.; Fellin, W.; Holzmann, M.; Engl, D.A.; Brandner, R.; Tessadri, R. Structure, mineralogy and geomechanical properties of shear zones of deep-seated rockslides in metamorphic rocks. Rock Mech. Rock Eng. 2017, 50, 419-438. [CrossRef]

81. Regmi, A.D.; Yoshida, K.; Dhital, M.R.; Devkota, K. Effect of rock weathering, clay mineralogy, and geological structures in the formation of large landslide, a case study from Dumre Besei landslide, Lesser Himalaya Nepal. Landslides 2013, 10, 1-13. [CrossRef]

82. Gurocak, Z.; Kilic, R. Effect of weathering on the geomechanical properties of the Miocene basalts in Malatya, Eastern Turkey. Bull. Eng. Geol. Environ. 2005, 64, 373-381. [CrossRef]

83. Eberli, G.P.; Baechle, G.T.; Anselmetti, F.S.; Incze, M.L. Factors controlling elastic properties in carbonate sediments and rocks. Lead. Edge 2003, 22, 654-660. [CrossRef]

84. Josh, M.; Esteban, L.; Piane, C.D.; Sarout, J.; Dewhurst, D.N.; Clennell, M.B. Laboratory characterisation of shale properties. J. Pet. Sci. Eng. 2012, 88, 107-124. [CrossRef]

85. Schaefer, L.N.; Kendrick, J.E.; Oommen, T.; Lavallée, Y.; Chigna, G. Geomechanical rock properties of a basaltic volcano. Front. Earth Sci. 2015, 3, 29. [CrossRef]

86. Jaques, D.S.; Marques, E.A.G.; Marcellino, L.C.; Leão, M.F.; Ferreira, E.P.S.; dos Santos Lemos, C.C. Changes in the Physical, Mineralogical and Geomechanical Properties of a Granitic Rock from Weathering Zones in a Tropical Climate. Rock Mech. Rock Eng. 2020, 53, 5345-5370. [CrossRef]

87. Ersoy, H.; Atalar, C.; Sünnetci, M.O.; Kolaylı, H.; Karahan, M.; Ersoy, A.F. Assessment of damage on geo-mechanical and micro-structural properties of weak calcareous rocks exposed to fires using thermal treatment coefficient. Eng. Geol. 2021, 284, 106046. [CrossRef]

88. Zhang, F.; An, M.; Zhang, L.; Fang, Y.; Elsworth, D. The role of mineral composition on the frictional and stability properties of powdered reservoir rocks. J. Geophys. Res. Solid Earth 2019, 124, 1480-1497. [CrossRef]

89. Sajid, M.; Coggan, J.; Arif, M.; Andersen, J.; Rollinson, G. Petrographic features as an effective indicator for the variation in strength of granites. Eng. Geol. 2016, 202, 44-54. [CrossRef]

90. Jeong, S.W.; Locat, J.; Leroueil, S.; Malet, J.P. Rheological properties of fine-grained sediment: The roles of texture and mineralogy. Can. Geotech. J. 2010, 47, 1085-1100. [CrossRef]

91. Tuğrul, A. The effect of weathering on pore geometry and compressive strength of selected rock types from Turkey. Eng. Geol. 2004, 75, 215-227. [CrossRef]

92. Jeng, F.S.; Weng, M.C.; Lin, M.L.; Huang, T.H. Influence of petrographic parameters on geotechnical properties of tertiary sandstones from Taiwan. Eng. Geol. 2004, 73, 71-91. [CrossRef]

93. Guéry, A.C.; Cormery, F.; Shao, J.F.; Kondo, D. A comparative micromechanical analysis of the effective properties of a geomaterial: Effect of mineralogical compositions. Comput. Geotech. 2010, 37, 585-593. [CrossRef]

94. Kumar, V.; Sondergeld, C.; Rai, C.S. Effect of mineralogy and organic matter on mechanical properties of shale. Interpretation 2015, 3, SV9-SV15. [CrossRef]

95. Liu, J.; Ding, W.; Wang, R.; Wu, Z.; Gong, D.; Wang, X.; Jiao, B. Quartz types in shale and their effect on geomechanical properties: An example from the lower Cambrian Niutitang Formation in the Cen'gong block, South China. Appl. Clay Sci. 2018, 163, 100-107. [CrossRef] 
96. Wong, L.Y.; Peng, J.; Teh, C.I. Numerical investigation of mineralogical composition effect on strength and micro-cracking behavior of crystalline rocks. J. Nat. Gas Sci. Eng. 2018, 53, 191-203. [CrossRef]

97. Singh, R.; Umrao, R.K.; Ahmad, M.; Ansari, M.K.; Sharma, L.K.; Singh, T.N. Prediction of geomechanical parameters using soft computing and multiple regression approach. Measurement 2017, 99, 108-119. [CrossRef]

98. Vernik, L.; Kachanov, M. Modeling elastic properties of siliciclastic rocks. Geophysics 2010, 75, 171-182. [CrossRef]

99. Allison, R.J.; Bristow, G.E. The effects of fire on rock weathering: Some further considerations of laboratory experimental simulation. Earth Surf. Processes Landf. J. Br. Geomorphol. Res. Group 1999, 24, 707-713. [CrossRef]

100. Xu, T.; Pruess, K. Numerical simulation of injectivity effects of mineral scaling and clay swelling in a fractured geothermal reservoir. In Proceedings of the Numerical Simulation of Injectivity Effects of Mineral Scaling and Clay Swelling in a Fractured Geothermal Reservoir, Lawrence, Berkeley National Lab, Berkeley, CA, USA, 10 May 2004.

101. Guo, Z.; Li, X.Y.; Liu, C.; Feng, X.; Shen, Y. A shale rock physics model for analysis of brittleness index, mineralogy and porosity in the Barnett Shale. J. Geophys. Eng. 2013, 10, 025006. [CrossRef]

102. Molins, S.; Trebotich, D.; Miller, G.H.; Steefel, C.I. Mineralogical and transport controls on the evolution of porous media texture using direct numerical simulation. Water Resour. Res. 2017, 53, 3645-3661. [CrossRef]

103. Kainthola, A.; Singh, P.K.; Verma, D.; Singh, R.; Sarkar, K.; Singh, T.N. Prediction of strength parameters of himalayan rocks: A statistical and ANFIS approach. Geotech. Geol. Eng. 2015, 33, 1255-1278. [CrossRef]

104. Lastra, G.; Jokovic, V.; Kanchibotla, S. Understanding the impact of geotechnical ore properties and blast design on comminution circuits using simulations. Miner. Eng. 2021, 170, 161-175. [CrossRef]

105. Brace, W.F. Dependence of fracture strength of rocks on grain size. In Proceedings of the 4th US Symposium on Rock Mechanics (USRMS), University Park, PA, USA, 30 March-1 April 1961; Volume 76, pp. 99-103.

106. Hoek, E. Rock Fracture under Static Stress Conditions; Report no: ME/TH/17; CSIR: Pretoria, South Africa, 1965.

107. Mendes, F.M.; Aires-Barros, L.; Rodrigues, F.P. The use of modal analysis in the mechanical characterization of rock masses. In Proceedings of the 1st ISRM Congress, Lisbon, Portugal, 25 September-1 October 1966.

108. Willard, R.J.; McWilliams, J.R. Microstructural techniques in the study of physical properties of rock. Int. J. Rock Mech. Min. Sci. Geomech. 1969, 6, 1-12. [CrossRef]

109. Hartley, A. A review of the geological factors influencing the mechanical properties of road surface aggregates. Q. J. Eng. Geol. 1974, 7, 69-100. [CrossRef]

110. Singh, S.K. Relationship among fatigue strength, mean grain size and compressive strength of a rock. Rock Mech. Rock Eng. 1988, 21, 271-276. [CrossRef]

111. Åkesson, U.; Lindqvist, J.; Göransson, M.; Stigh, J. Relationship between texture and mechanical properties of granites, central Sweden, by use of image-analysing techniques. Bull. Eng. Geol. Environ. 2001, 60, 277-284. [CrossRef]

112. French, W.J.; Kermani, S.; Mole, C.F. Petrographic evaluation of aggregate parameters. In Proceedings of the 8th Euro seminar on Microscopy Applied to Building Materials, Athens, Greece, 4-7 September 2001.

113. Räisänen, M.; Kupiainen, K.; Tervahattu, H. The effect of mineralogy, texture and mechanical properties of anti-skid and asphalt aggregates on urban dust. Bull. Eng. Geol. Environ. 2003, 62, 359-368. [CrossRef]

114. Price, N.J. The compressive strength of coal measure rocks. Colliery Eng. 1960, 37, 283-292.

115. Přikryl, R. Some microstructural aspects of strength variation in rocks. Int. J. Rock Mech. Min. Sci. 2001, 38, 671-682. [CrossRef]

116. Wong, R.H.; Chau, K.T.; Wang, P. Microcracking and grain size effect in Yuen Long marbles. Int. J. Rock Mech. Min. Sci. Geomech. Abstr. 1996, 33, 479-485. [CrossRef]

117. Hareland, G.; Polston, C.E.; White, W.E. Normalized rock failure envelope as a function of rock grain size. Int. J. Rock Mech. Min. Sci. Geomech. Abstr. 1993, 30, 715-717. [CrossRef]

118. Fahy, M.P.; Guccione, M.J. Estimating strength of sandstone using petrographic thin-section data. Bull. Assoc. Eng. Geol. 1979, 16, 467-485. [CrossRef]

119. Chatterjee, R.; Mukhopadhyay, M. Petrophysical and geomechanical properties of rocks from the oilfields of the Krishna-Godavari and Cauvery Basins, India. Bull. Eng. Geol. Environ. 2002, 61, 169-178. [CrossRef]

120. Tamrakar, N.K.; Yokota, S.; Shrestha, S.D. Relationships among mechanical, physical and petrographic properties of Siwalik sandstones, Central Nepal Sub-Himalayas. Eng. Geol. 2007, 90, 105-123. [CrossRef]

121. Ozturk, C.A.; Nasuf, E.; Kahraman, S.A. Estimation of rock strength from quantitative assessment of rock texture. J. South. Afr. Inst. Min. Andm. 2014, 114, 471-480.

122. Ersoy, A.; Waller, M.D. Textural characterization of rocks. Eng. Geol. 1995, 39, 123-136. [CrossRef]

123. Ozturk, C.A.; Nasuf, E.; Bilgin, N. The assessment of rock cutability, and physical and mechanical rock properties from a texture coefficient. J. South. Afr. Inst. Min. Metall. 2004, 104, 397-402. 
124. Alber, M.; Kahraman, S. Predicting the uniaxial compressive strength and elastic modulus of a fault breccia from texture coefficient. Rock Mech. Rock Eng. 2009, 42, 117-125. [CrossRef]

125. Aagaard, B. Strength Anisotropy of Rocks. Master's Dissertation, Norwegian Institute of Technology, Trondheim, Norway, 1976; p. 104.

126. Nasseri, M.H.; Rao, K.S.; Ramamurthy, T. Failure mechanism in schistose rocks. Int. J. Rock Mech. Min. Sci. 1997, 34, 219-223. [CrossRef]

127. Khanlari, G.R.; Heidari, M.; Sepahigero, A.A.; Fereidooni, D. Quantification of strength anisotropy of metamorphic rocks of the Hamedan province, Iran, as determined from cylindrical punch, point load and Brazilian tests. Eng. Geol. 2014, 169, 80-90. [CrossRef]

128. Ali, E.; Guang, W.; Weixue, J. Assessments of strength anisotropy and deformation behavior of banded amphibolite rocks. Geotech Geol. Eng. 2014, 32, 429-438. [CrossRef]

129. Hobbs, D.W. The tensile strength of rocks. Int. J. Rock Mech. Min. Sci. Geomech. Abstr. 1963, 1, 385-396. [CrossRef]

130. McCabe, W.M.; Koerner, R.M. High pressure shear strength investigation of an anisotropic mica schist rock. Int. J. Rock Mech. Min. Sci. Geomech. 1975, 12, 219-228. [CrossRef]

131. Brown, E.T.; Richards, L.R.; Barr, M.V. Shear strength characteristics of Delabole slate. Proc. Conf. Rock Eng. 1977, 1, 31-51.

132. Donath, F. A triaxial pressure apparatus for testing of consolidated or unconsolidated materials subjected to pore pressure. In Testing Techniques for Rock Mechanics; American Society for Testing and Materials: Conshohocken, PA, USA, 1966 ; pp. 41-55.

133. Ambrose, J. Failure of Anisotropic Shales under Triaxial Stress Conditions. Ph.D. Thesis, Imperial College London, Department of Earth Science and Engineering, London, UK, 2014.

134. Saeidi, O.; Rasouli, V.; Vaneghi, R.G.; Gholami, R.; Torabi, S.R. A modified failure criterion for transversely isotropic rocks. Geosci. Front. 2014, 5, 215-225. [CrossRef]

135. Duveau, G.; Shao, J.F.; Henry, J.P. Assessment of some failure criteria for strongly anisotropic geomaterials. Mech. Cohesive-Frict. Mater. Int. J. Exp. Model. Comput. Mater. Struct. 1998, 3, 1-26. [CrossRef]

136. Hill, R. A theory of the yielding and plastic flow of anisotropic metals. Proc. R. Soc. London. Ser. A. Math. Phys. Sci. 1948, 193, 281-297.

137. Goldenblat, I.; Kopnov, V.A. Strength of glass-reinforced plastics in the complex stress state. Polym. Mech. 1966, 1, 54-59. [CrossRef]

138. Pariseau, W.G. Plasticity theory for anisotropic rocks and soil. In Proceedings of the 10th US Symposium on Rock Mechanics (USRMS), Austin, TX, USA, 22 May 1968.

139. Tsai, S.W.; Wu, E.M. A general theory of strength for anisotropic materials. J. Compos. Mater. 1971, 5, 58-80. [CrossRef]

140. Boehler, J.P.; Sawczuk, A. Equilibre limite des sols anisotropes. J. De Mec. 1970, 5-13.

141. Boehler, J.P.; Sawczuk, A. On yielding of orientated solids. Acta Mech. 1977, 27, 185-192. [CrossRef]

142. Boehler, J.P. Contributions the Oriques et Expérimentales a L'etude des Milieux Plastiques Anisotropes'. Ph.D. Thesis, Sciences appliquées, Grenoble, France, 1975.

143. Allirot, D.; Boehler, J.P. Evolution of mechanical properties of a stratified rock under confining pressure. In Proceedings of the 4th ISRM Congress, Montreux, Switzerland, 2-8 September 1979.

144. Boehler, J.P.; Raclin, J. Ecrouissage anisotrope des matériaux orhtotropes pré de formes. J. De Mec. 1982, $23-44$.

145. Cazacu, O.; Cristescu, N.D. Failure of Anisotropic Compressible Shale; University of California: Los Angeles, CA, USA, 1995.

146. Jaeger, J.C. Shear failure of transversely isotropic rock. Geol. Mag. 1960, 97, 65-72. [CrossRef]

147. McLamore, R.; Gray, K.E. The mechanical behavior of transversely isotropic sedimentary rocks. Transit. Am. Soc. Mech. Eng. 1967, $89,62-76$.

148. Single, B.; Goel, R.K.; Mehrotra, V.K.; Garg, S.K.; Allu, M.R. Effect of intermediate principal stress on strength of anisotropic rock mass. Tunn. Undergr. Space Technol. 1998, 13, 71-79. [CrossRef]

149. Ramamurthy, T.; Venkatappa Rao, G.; Singh, J. A strength criterion for anisotropic rocks. In Proceedings of the 5th Australia-New Zealand Conference on Geomechanics, Sydney, Australia, 22-26 August 1988.

150. Walsh, J.B.; Brace, W.F. A fracture criterion for brittle anisotropic rock. J. Geophys. Res. 1964, 69, 3449-3456. [CrossRef]

151. Hoek, E. Fracture of anisotropic rock. J. Afr. Inst. Min. Metall. 1964, 64, 501-518.

152. Hoek, E. Strength of jointed rock masses. Geotechnique 1983, 33, 187-223. [CrossRef]

153. Hoek, E.; Brown, E.T. Empirical strength criterion for rock masses. J. Geotech. Eng. Div. 1980, 106, 1013-1035. [CrossRef]

154. McClintock, F.A.; Walsh, J.B. Friction on Griffith Cracks in Rocks under Pressure. ASME 1962, 2, $1015-1021$.

155. Olszak, W.; Urbanowski, W. The plastic potential and the generalized distortion energy in the theory of non-homogeneous anisotropic elastic-plastic bodies. Arch. Mech. Stos 1956, 8, 671-694.

156. Li, Y.; Zhang, H.; Chen, M.; Meng, X.; Shen, Y.; Liu, H.; Lu, Y. Strength criterion of rock mass considering the damage and effect of joint dip angle. Sci. Rep. 2022, 12, 2601. [CrossRef]

157. Dafalias, Y.F.; Popov, E.P. A model for nonlinearity hardening material for complex loading. Acta Mech. 1979, $21,173-192$. [CrossRef] 
158. Dafalias, Y.F. Issues on the constitutive formulation at large elastoplastic deformations, Part 1: Kinematics. Acta Mech. 1987, 69, 119-138. [CrossRef]

159. Nova, R.; Sacchi, G. A generalized failure condition for orthotropic solids. Mech. Behav. Anisotropic Solids/Comportment Méchanique Des Solides Anisotropes 1979, 623-641.

160. Raclin, J. Contributions Théoriques et Expérimentales à L'étude de la Plasticité, de L'écrouissage et de la Rupture des Solides Anisotropes. Ph.D. Dissertation, Grenoble, Paris, France, 1984; p. 623.

161. Cazacu, O.; Cristescu, N.D. A paraboloid failure surface for transversely isotropic materials. Mech. Mater. 1995, 31, 381-393. [CrossRef]

162. Salajegheh, S.; Shahriar, K.; Jalalifar, H.; Ahangari, K. Numerical and experimental research of rock failure mechanism and its dependence on mi Hoek-Brown failure criterion. Min. -Geol.-Pet. Bull. 2021, 36, 157-165. [CrossRef]

163. Kusabuka, M.; Takeda, H.; Kojo, H.; Tonegawa, T. Anisotropic yield function for rocks and evaluation of material parameters. Doboku Gakkai Ronbunshu 1999, 631, 205-220. [CrossRef]

164. Pietruszczak, S.; Mroz, Z. On failure criteria for anisotropic cohesive-frictional materials. Int. J. Numer. Anal. Methods Geomech. 2001, 25, 509-524. [CrossRef]

165. Lee, Y.K.; Pietruszczak, S. Application of critical plane approach to the prediction of strength anisotropy in transversely isotropic rock masses. Int. J. Rock Mech. Min. Sci. 2008, 45, 513-523. [CrossRef]

166. Mróz, Z.; Maciejewski, J. Critical plane approach to analysis of failure criteria for anisotropic geomaterials. Bifurc. Instab. Degrad. Geomater. 2011, 11, 69-89.

167. Casagrande, A.; Carillo, N. Shear failure of anisotropic materiials, Journal oy the Boston Society oy Civil Engineers. Contrib. Soil Mech. 1944, 31, 1941-1953.

168. Ashour, H.A. A compressive strength criterion for anisotropic rock materials. Can. Geotech. J. 1988, 25, 233-237. [CrossRef]

169. Zhao, Q.D.; Liu, Z.S.; Qi, L. Strength criteria for anisotropic rocks and experimental studies. Soc. Pet. Eng. 1992, SPE 25302.

170. Tiwari, R.P.; Rao, K.S. Response of an anisotropic rock mass under polyaxial stress state. J. Mater. Civ. Eng. 2007, 19, $393-403$. [CrossRef]

171. Zhang, L.; Zhu, H. Three-dimensional Hoek-Brown strength criterion for rocks. J. Geotech. Geoenviron. Eng. 2007, 133, 1128-1135. [CrossRef]

172. Lee, Y.K.; Pietruszczak, S.; Choi, B.H. Failure criteria for rocks based on smooth approximations to Mohr-Coulomb and HoekBrown failure functions. Int. J. Rock Mech. Min. Sci. 2012, 56, 146-160. [CrossRef]

173. Murrell, S.A.F. The effect of triaxial stress systems on the strength of rocks at atmospheric temperatures. Geophys. J. Int. 1965, 10, 231-281. [CrossRef]

174. Barron, K. Brittle fracture initiation in and ultimate failure of rocks: Part I-Anisotropic rocks: Theory. Int. J. Rock Mech. Min. Sci. Geomech. Abstr. 1971, 8, 553-563. [CrossRef]

175. Ladanyi, B.; Archambault, G. Evaluation of shear strength of a jointed rock mass. In Proceedings of the 24th International Geological Congress, Montreal, QC, Canada, 22 June 1979; Volume 1, pp. 249-270.

176. Bieniawski, Z.T. Estimating the strength of rock materials. J. South. Afr. Inst. Min. Metall. 1974, 74, 312-320. [CrossRef]

177. Smith, M.B.; Cheatham, J.B., Jr. An anisotropic compacting yield condition applied to porous limestone. Int. J. Rock Mech. Min. Sci. Geomech. 1980, 17, 159-165. [CrossRef]

178. Yoshinaka, R.; Yamabe, T. A Strength Criterion of Rocks and Rock Masses. In Proceedings of the ISRM International Symposium, Aachen, Germany, 26-28 May 1981.

179. Zhang, G.Q. Rock failure with weak planes by self-locking concept. Int. J. Rock Mech. Min. Sci. 2009, 46, 974-982. [CrossRef]

180. Saroglou, H.; Tsiambaos, G. A modified Hoek-Brown failure criterion for anisotropic intact rock. Int. J. Rock Mech. Min. Sci. 2007, 45, 223-234. [CrossRef]

181. Tien, Y.M.; Kuo, M.C.; Juang, C.H. An experimental investigation of the failure mechanism of simulated transversely isotropic rocks. Int. J. Rock Mech. Min. Sci. 2006, 43, 1163-1181. [CrossRef]

182. Horino, F.G.; Ellickson, M.L. A Method for Estimating Strength of Rock Containing Planes of Weakness; US Department of Interior, Bureau of Mines: Washington, DC, USA, 1970.

183. Jaeger, J.C.; Cook, N.G. Fundamentals of Rock Mechanics, 3rd ed.; Chapman and Hall: London, UK, 1979.

184. Nova, R. The failure of transversely isotropic rocks in triaxial compression. Int. J. Rock Mech. Min. Sci. Geomech. 1980, 17, 325-332. [CrossRef]

185. Nova, R. An extended Cam Clay model for soft anisotropic rocks. Comput. Geotech. 1986, 2, 69-88. [CrossRef]

186. Rafiai, H. New empirical polyaxial criterion for rock strength. Int. J. Rock Mech. Min. Sci. 2011, 48, 922-931. [CrossRef]

187. Askaripour, M.; Saeidi, A.; Rouleau, A.; Mercier-Langevin, P. Rockburst in underground excavations: A review of mechanism, classification, and prediction methods. Undergr. Space 2022. [CrossRef]

188. Dehkordi, A.R. 3D Finite Element Cosserat Continuum Simulation of Layered Geomaterials. Ph.D. Thesis, University of Toronto, Department of Civil Engineering, Toronto, ON, Canada, 2008.

189. Song, Z.; Zhang, J. Research on the progressive failure process and fracture mechanism of rocks with the structural evolution perspective. J. Struct. Geol. 2022, 154, 104484. [CrossRef] 
190. Song, Z.; Zhang, J. Progressive failure mechanical behaviour and response characteristics of sandstone under stress-seepage coupling. J. Geophys. Eng. 2021, 18, 200-218. [CrossRef]

191. Zhang, J.; Song, Z.; Wang, S. Experimental investigation on permeability and energy evolution characteristics of deep sandstone along a three-stage loading path. Bull. Eng. Geol. Environ. 2021, 80, 1571-1584. [CrossRef] 